\title{
A Monograph of the genus Inocybe, Karsten.
}

\author{
BY \\ GEORGE MASSEE, F.L.S., \\ Principal Assistant, Horbarium, Royal Botanic Gardens, Kew. \\ With Plate XXXII.
}

$\mathrm{HE}$ word Inocybe was first used by Fries $^{1}$ to designate a section
of the genus Agaricus, which at the time included the majority of gill-bearing Fungi.

Karsten was the first to use Inocybe in a strictly generic sense ${ }^{2}$; in fact this author raised all the sectional names employed by Fries in dividing up his huge genus Agaricus to generic value; a step which has received the assent of most modern mycologists.

The species of Inocybe are by common consent looked upon as difficult to recognize in the field ; in fact all past attempts to do so have resulted in failure and almost hopeless confusion, and I think it will be generally conceded that the Friesian method of study, depending on naked-eye, or at most, pocket-lens characters, is wholly inadequate. One principal reason for this state of things is the great variability presented by the pileus of the same species under different weather conditions. A species may have the surface of the pileus normally smooth and silky; or in other words, the specimen on which a species was originally founded happened to have a pileus of this nature; consequently this feature constitutes one of the salient characters in its diagnosis, where macroscopic features alone are taken into consideration. Unfortunately all who have had a considerable amount of experience in the field, know perfectly well that a Fungus usually having a pileus of the nature defined above may, under other conditions of growth, have the surface of the pileus broken up into scales. Now this change technically removes the Fungus from the section 'Velutini,' and places it in the section 'Laceri.' As already stated, an experienced

1 Syst. Myc. Fang. I, p. 254 (18a1).

- Rysslends, Finlands, och den Skandinaviska Halfös Hattsvampar; forming vol. rxxil, Finlands Natur och Folk, p. 453 (1879).

[Annals of Botany, Vol. XVII. No. LXXI Jaly, 1904.] 


\section{Massee.-A Monograph of the genus Inocybe, Karsten.}

mycologist is not always deceived by such a superficial change, but less experienced persons often are. The beginner fails to locate in the 'Laceri' a Fungus which in reality belongs to the 'Velutini,' and a 'new species ' is the result.

Other causes leading to confusion, and quite unnecessary multiplication of names, are as follows.

Personally I consider that colour should not constitute part of a specific diagnosis ; however, as a matter of fact, by almost common consent it does so. Where the colours are clear and well defined, as in many genera, there is no serious objection to the practice, but in the genus Irocybe, where the colour of dozens of closely allied species is some shade of brown, the attempts of different authors to convey to others the particular shade of brown is, to say the least, perplexing. When a definition of odours is attempted matters are still worse. As an example, Weinmann (Fung. Ross, p. 194) says of Inocybe Trinii, his own species, 'odore valde suavis et fere caryophyllaceus!' Bresadola (Fung. Trid., ii, p. I4), speaking of the same Fungus, says, 'odore forti terreo.' Numerous such differences of opinion are extant, and the obvious conclusion is that mycologists cannot define the characteristics of a smell in words.

Schaeffer, Persoon, Bulliard, Bolton, Krombholz, and other pioneers in mycology, have left evidence of their untiring enthusiasm in the pursuit of their favourite study, in the form of coloured figures of many hundred different kinds of Fungi. These they named and described to the best of their ability; but it must be admitted that in numerous instances the figures are somewhat grotesque, and in the best cases rarely give more than a general idea of the species intended, from an artistic rather than a scientific standpoint. Again, the principal characteristic of the specific descriptions furnished by the above-named authors is their extreme brevity, which in many instances renders identification of the exact species they had in view somewhat uncertain, or often practically impossible for ordinary mortals to accomplish.

Unfortunately for mycology there have of late years always been two or three extraordinary people amongst us, who appear to be firmly convinced that their special function on earth is to indicate, without possibility of error, the exact species the old authors had in view. By such clairvoyants, species of Fungi that have been known by a particular name for a considerable period of time, and universally accepted, are suddenly discovered to be nothing more than the identical kind figured and described by some ancient author. An exchange of names follows, and the discoverer rewards himself by adding his own name after the new combination.

Even this method could be accepted if there was any hope for finality, but in the absence of types, and the figures and descriptions being as stated above, there is room for no such hope. 


\section{Massee.-A Monograph of the genus Inocybe, Karsten. $46 \mathrm{I}$}

Not unfrequently the confusion alluded to is intensified by changing the specific name, on the ground that the one originally used was not classically correct.

A law of their own formulating is the justification for this act.

By such tactics the champions of scientific accuracy, and of justice to old authors, carefully eliminate not only the original specific name, but also that of the original author; and why? Solely for the purpose of posing as the founder of a species; and in their anxiety to accomplish this object, scientific accuracy and justice to the old authors are alike forgotten.

This method of procedure goes behind the rule, that the name following a species should be that of the person who first placed it in the right genus.

I am daily expecting the advent of the person who will boldly contest the validity of all specific names conferred up to the present, on the ground that their characteristics are not defined in classical Latin. At all events his argument would possess the merit of being as logical as many of those used at present for a similar purpose.

The genus Inocybe contains I I 2 distinct species, and as a preliminary to the preparation of this monograph, 417 specimens were examined microscopically for the purpose of obtaining camera drawings and measurements of the spores, cystidia, and basidia. These specimens included those contained in the Kew Herbarium, supplemented by types and authentic specimens kindly communicated by other mycologists.

As a result of this detailed examination of the structure of the hymenium in the various species, the fact has become apparent that perhaps in no other genus included in the Agaricaceae are characters of specific value more distinctly marked, than those presented by the spores, cystidia and basidia in the genus Inocybe.

For systematic purposes the spores may be divided into two primary groups: (1) epispore smooth; (2) epispore rough, that is, furnished with projections of some kind. In the first group, the most general form I have called pip-shaped, on account of the resemblance to the pip or seed of an apple. A second type of smooth spore is that of a long, narrow ellipse with obtuse ends; this is termed elliptico-cylindrical. This form of spore is in some species very slightly curved. In a third form, only known in one species-I. rhombospora, Massee, from India-the spores are distinctly rhomboidal in outline, and much compressed laterally (Fig. 4). In the second group the spores are either globose or irregularly oblong. In all there is a more or less pronounced apiculus, or narrowed end, corresponding to the point of attachment of the spore to the sterigma. The ornamentation of the epispore is included under two heads: (I) Spinulose, when the epispore bears slender pointed spines. $U_{p}$ to the present this type of epispore ornamentation is, confined to one species-1. Gaillardi, Gillet, 


\section{Massee.-A Monograph of the genus Inocybe, Karsten.}

a Fungus common to Europe and America (Fig. I I). (2) Nodulose; this type of epispore marking varies considerably in different species. The most frequent form is where the epispore is sparsely covered with large, blunt warts or papillae; in a second type the nodules are only very slightly raised, giving the spore a wavy outline when seen in optical section (Fig. 6); a third type has the nodules elongated into blunt finger-shaped papillae (Fig. 12). The cystidia are present under two forms: ventricose, having a pronounced swelling some distance below the apex (Fig. 8) ; fusoid, when more or less spindle-shaped (Fig. 10). The tips of cystidia are sometimes crowned with a brownish mass resembling a conglomeration of small crystals. This feature is by some mycologists considered as of importance, and finds a place in specific descriptions. This character is however absolutely valueless; the accumulation is simply nothing more than mucilage which escapes from the interior of the cystidium after the deliquescence of the thin portion of wall at its apex. If the air continues to be moist the escaping mucilage remains liquid and numerous falling spores are caught, forming a dense mass at the apex of the cystidium (Fig. 9). On the other hand, if the air is dry when the mucilage escapes, it dries up and contracts into a rugged mass. When the mucilage once dries it is afterwards insoluble in water (Fig. 8).

True cystidia are only met with on the surface of the gills. Their walls are very thick and highly refringent, and when free from colour are very apt to be overlooked, even when specially sought after. This difficulty can be overcome by running in under the cover-glass a weak solution of the stain called 'azurblau,' dissolved in water, and adding potassic hydrate until the solution assumes a clear red colour. The cystidia are the first to take up the stain, which gradually extends to all the tissues. This stain will be found of general use in the examination of Fungi.

The margins of the gills are frequently whitish, and under a pocketlens appear minutely fimbriate. This appearance is due to the presence of large clavate or fusoid cells, which are in some species arranged in little groups, when the margin of the gill is described as serrulate.

These marginal cells are often as large as cystidia, from which they differ in having thin walls, and not deliquescing at the apex and exuding mucilaginous matter. They also differ in origin, being modified elements of the hymenium, basidia and paraphyses; whereas cystidia originate from tramal cells, and push up between the elements of the hymenium, until they eventually project some distance above the level of the hymenium. Cystidia are sometimes spoken of as excretory organs, but in reality nothing definite is known as to their functions, which presumably differ in different genera, judging from the variety in structure presented.

It is premature to speak of the geographical distribution of Inocybe, considering that out of 112 known species, 80 occur in Europe, and 36 in 


\section{Massee.-A Monograph of the genus Inocybe, Karsten. 463}

America, all from the United States. The following table gives the distribution so far as at present known:-

\begin{tabular}{cllll} 
Europe. & \multicolumn{1}{c}{ Asia. } & Africa. & \multicolumn{1}{c}{ America. } & Australasia. \\
Total 80. & Total 3. & Total I. & Total 36. & Total 3. \\
Endemic 69. & All endemic. & Endemic. & Endemic 25. & Endemic 2.
\end{tabular}

Eleven species are common to Europe and America, and one Australasian species is also European.

In the following arrangement of the species the primary sections depend on the presence or absence of cystidia, and on the rough or smooth epispore. There will undoubtedly be a difference of opinion as to the relative value of the above characters in the discrimination of species. On the other hand, perhaps all will agree as to the advantage of having the characters of cystidia and spores, obtained from type specimens, added to the original diagnosis of species from which they were originally omitted. This I have been enabled to do through the generosity of the following mycologists in giving or lending type specimens, and to each of whom I express my thanks:-Dr. E. Boudier, Professor Dr. F. R. Kjellman, Dr. P. Hariot, Professor C. H. Peck, Dr. L. Romell.

\section{Inocybe, Karsten.}

Pileus symmetrical, flesh thin, covered with a fibrillose veil which becomes either longitudinally cracked, or broken up into squamules or squarrose scales, dry or rarely viscid; gills adnate, adnexed or nearly free, brownish or dingy; spores pale brown, epispore smooth, warted or spinulose; cystidia often present; stem central, slender, fibrillose, often peronate with squamules or squarrose scales up to the imperfectly defined annular zone.

The genus Inocybe is most closely allied to Hebeloma, under which at one time it was included. The last named differs in the constantly viscid, pelliculose veil which is never fibrous and silky, whereas in Inocybe the veil covering the pileus is always distinctly silky or fibrous, even when viscid.

The majority of species grow on the ground in woods or damp, shady places.

\section{Key to THE SPECIES.}

I. Cystidia present.

\section{A. Spores rough.}

* Stem whitish, or pallid.

* Stem coloured.

II. Cystidia absent.

[Spores rough, no knowledge of cystidia.

* Stem whitish, or pallid.

* Stem coloured.] 
III. Cystidia present.

\section{B. Spores smooth.}

* Stem whitish, or pallid.

+ Gills brownish, ochraceous or cinnamon.

+ Gills tinged olive.

H+ Gills tinged violet.

** Stem coloured.

+ Gills ochraceous, brown or cinnamon.

t+ Gills tinged olive.

H+ Gills tinged violet.

IV. Cystidia absent.

- Stem whitish, or pallid.

+ Gills brownish, ochraceous or cinnamon.

"t+ Gills tinged olive."

** Stem coloured.

† Gills browrish, ochraceous or cinnamon.

t+ Gills tinged olive.

[Spores smooth, no knowledge of cystidia.

- Pileus dark-coloured.

* Pileus light-coloured.]

The two sections in square brackets include those species respecting which our knowledge is at present incomplete, no information being included in the original diagnosis respecting cystidia.

Abbreviations used in the specific descriptions:-

$P .=$ pileus $; g .=$ gills $; s .=$ stem $; s p .=$ spores $; c .=$ cystidia .

A. SPORES Rough.

I. Cystidia present.

* Stem whitish, or pallid.

Gbrosa, Karst., Hattsv., p. 460; Sacc., Syll. v, p. 779 ; Bres., Fung. Trid., i, tab. 56 ; Ag. fibrosus, Sowerb., Fung., tab. 414 ; Ag. fastigiatus, Britz., Derm. Sud. Bay. p. 4, f. 27 ; Ag. (Ino.) ineditus, Britz., Hym. Südb., p. I50, f. 143; I. inedita, Sacc., Syll. v, p. 780 .

P. campanulate, then expanded and gibbous, silky, whitish to pale yellow-brown, edge cracking, 6-10 cm., flesh thick, white; g. nearly free, narrowed behind, dingy ochre; s. solid, stout, narrowed and floccose upwards, whitish, 7-II cm.; sp. irregularly oblong, apiculate, slightly nodulose, 10-12 $\times 7-7 \cdot 5 \mu$; c. ventricose, $45^{-}$ $60 \times 12-15 \mu$

In pine woods, \&c. Britain, France, Germany, Austria, Russia, Finland, Sweden, Holland.

One of the largest species. Differs from $I$. perlata in having warted spores.

(Sowerby's type examined.) 


\section{Massee.-A Monograph of the genus Inocybe, Karsten. 465}

Bresadolae, Massee ; I. repanda (Bull.) Bres., Fung. Trid., pl. I I9, f. I. P. campanulate, then expanded and umbonate, edge sinuate and wavy, lubricous, whitish and covered with rosy-tawny fibrils, disc even and rosy-tawny, $3-6 \mathrm{~cm}$; $\mathrm{g}$. crowded, white, then dull cinnamon becoming rufous, edge white-fimbriate, rounded behind and free ; s. solid, whitish, pruinose, at length tinged with rosy-tawny, apex striate, base ventricose or slightly turbinately bulbous, 3-5 cm. long, 5-6 mm. thick; sp. elongated, tuberculose, 8-10 $\times 6 \mu ;$ c. ventricose, $60-70 \times 17-20 \mu$. Flesh white, tinged red when broken. Smell pleasant.

On the ground. Austria.

Notwithstanding Bresadola's rider 'Speciem hanc genuinam Ag. repandum, Bull. sistere vix dubitaret,' I cannot admit the identity. This question I consider to have been settled by Berkeley more than half a century ago, and moreover Bresadola has obviously disregarded Bulliard's text relating to his Fungus, and relied entirely on figures in his determination. Berkeley's original account of the Fungus he considered to be Bulliard's plant, and which he placed in the section Entoloma, is as follows :-

Pilews 1-2 inches broad, conic, obtuse, at length expanded, very fleshy, the margin incurved and lobed, pale whitish ochraceous, with a few streaky shades, clothed with a very close, adpressed indistinct silkiness. Gills pale dull-rose, broad in front. Sporules round, rose-coloured. Stem I inch high, 3 lines thick, white, beautifully adpresso-sericeus, composed of fibrous cells, distinct from those of the pileus. Odour like that of fresh meal. My specimens agree precisely with Bulliard's plant quoted above, except that the colour is not so lively. He says expressly that the seminal powder is 'rougeatre,' which can bardly apply to any species of the subgenus Inocybe (Eng. Flor., v, Fungi, p. 78 ).

Rolland (Bull. Soc. Myc. Fr., xix, 333, pl. 16, figs. 1-3, 1903) has collected some specimens in France, respecting which he writes:- 'Dans ces champignons, où il nous est impossible de voir autre chose que le véritable type de l Inocybe repanda Bull., les spores sont ovales et lisses.'

This makes the fourth species that has been stated to be undoubtedly the Agaricus repandus, Bull.

asterospora, Quél., Flor: Myc., p. 100 (1888); Sacc., Syll. v, p. 780 ; Ag. (Ino.) asterosporus, Quél., Bull.. Soc. Bot. Fr., xxvi, p. 50; Soç., Sci. Nat. Rouen, 1879, tab. 2, f. 6 ; Cke., Ill., pl. $3^{8} 5$; I. subrimosa, Sacc., Syll. ix, p. 100 ; Clypeus subrimosus, Karst., Symb. ad Myc. Fenn., xxviii, in Med. Soc. Faun. et Flor. Fenn., r 888 , p. $3^{8}$ (non Cooke, Ill. pl. 402, as stated by Karsten).

P. campanulate, then expanded and umbonate, even and almost glabrous, becoming rimose and silky-fibrous, from brownish to dingy cinnamon, $2-5 \mathrm{~cm}$; $\mathrm{g}$. emarginate, ventricose, dingy cinnamon; s. cylindrical, minutely emarginately bulbous, almost glabrous, whitish, sometimes becoming tinged red and streaked with brown fibrils, $5^{-8} \mathrm{~cm}$.; sp. subglobose, coarsely stellately-nodulose, 10-1 $3 \mu$; c. ventricose, fairly numerous, $60-75 \times 12-16 \mu$

On the ground in woods, \&c. Britain, France, Finland, United States (' 55 I 4 , C. Wright, Connecticut,' under $I$. rimosa in Herb. Kew.).

Superficially resembling $I$. rimosa, with which it was at one time confounded, 


\section{Massee.-A Monograph of the genus Inocybe, Karslen.}

differing in the nodulose spores. Near to I. margarispora, which differs in the absence of cystidia.

(Specimen of $I$. asterospora from Quélet, and of $I$. subrimosa from Karsten examined.)

proximella, Karst., Symb. Myc., ix, p. 44 ; Sacc., Syll. v, p. 78 r.

$P$. conico-convex, then expanded and umbonate, even, then longitudinally fibrously cracked, pallid, the disc and especially the umbo passing into rusty brown or bay, 2-4 cm.; g. adnate, crowded, ventricose, pallid then tan, finally brown; s. stuffed, slightly narrowed upwards, usually ascending from the base, sometimes wavy, subfibrillose, pallid, flesh white, $6-8 \mathrm{~cm}$; sp. irregularly oblong, slightly nodulose, 8Io $\times 5-7 \mu$; c. ventricose, $55-70 \times 12-16 \mu$, abundant.

On the ground in woods. Finland.

Superficially resembling $I$, asterospora, but distinguished by the ventricose gills, and more especially by the irregularly oblong spores.

(Type specimen from Karsten examined.)

praetervisa, Quél., in Bresad., Fung. Trid., i, p. 35, tab. $3^{8}$; Quél., Flor. Myc., p. 99 ; Sacc., Syll. v, p. 782.

P. conico-campanulate, then expanded and broadly umbonate, margin often lobed and split when old, lubricous, soon beautifully longitudinally rimose, fibrillose, disc glabrous, ochraceous tan, sometimes brownish towards the edge, $3-6 \mathrm{~cm}$.; $\mathrm{g}$. crowded, almost free, white then greyish-cinnamon, edge fimbriate; s. solid, terete, glabrous or subfibrillose, apes pruinose, white then straw-colour, base minutely marginately bulbous, $4-7 \mathrm{~cm}$; sp. irregularly-oblong, nodulose, Io-I I $\times 5^{-6} \mu$; c. ventricose or fusoid, $55-75 \times 20-30 \mu$. Flesh white.

On the ground among herbage in pine woods. · France.

Distinguished from allies by the lubricous pileus.

eriocephala, Sacc., Syll. v, p. 79I ; Ag. eriocephalus, Fries, Mon., i, p. 35 I ; Fries, Icon. Sel., ii, p. 9, tab. I10, f. 4.

P. hemispherical, then convex, obtuse, silky, dry, white with a dull yellow tinge, and with white downy flecks, especially near the margin, $1-1.5 \mathrm{~cm}$.; g. adnate, narrow, pallid then rusty; 8. fistulose, silky-fibrillose, or sometimes squamulose, whitish, 5-8 cm.; sp. irregularly oblong, apiculate, very slightly nodulose, some almost smooth, $6-7 \times 5 \mu$; c. ventricose, scattered, $40-50 \times 10-13 \mu$.

On rotten wood. Sweden.

Marked by the pale, obtuse pileus. more or. less covered with downy flecks, and the small, very slightly nodulose spores.

(Specimen from Fries examined.)

albodisca, Peck, 51 Rep. State Mus., p. 290 (1897); Sacc., Syll. xvi, p. 90.

P. conical or campanulate, umbonate, smooth and whitish at the disc when fresh and moist, elsewhere dingy yellowish-brown or lilac-brown, paler and slightly fbrillose or silky when dry, longitudinally rimose, about $2.5 \mathrm{~cm}$.; g. rounded behind, somewhat crowded, whitish then rather rusty; s. equal, solid, striate, glabrous or slightly pruinose at the apex, pallid, $3-5 \mathrm{~cm}$; sp. suboblong, slightly nodulose, 7-9 $\times 5-6 \mu$; c. abundant, some very ventricose, others almost fusiform, 40$60 \times 14-20 \mu$ 


\section{Massee.-A Monograph of the genus Inocybe, Karsten. 467}

Under spruce and balsam fir-trees. United States (North Elba, Essex Co.).

Easily distinguished from all other species of this genus known to me, by the whitish umbonate apex of the pileus (Peck).

(Peck's type examined.)

curvipes, Karst., Hedw., I89o, p. 176 ; Sacc., Syll. ix, p. 97.

P. convex, then expanded, unequal, obtuse, adpressedly fibrillose or fibrillosely squamulose, becoming glabrous, brown or fuscous becoming paler, $2-2.5 \mathrm{~cm} ; \mathrm{g}$. adnexed, seceding, crowded, whitish then brownish; s. solid, curved, flexuous or twisted, narrowed downwards, fibrillose, pallid, about $3 \mathrm{~cm}$; sp. irregularly ellipticoblong (angulato-ellipsoideis), 9-I $5 \times 5-7 \mu$; c. fusoid-ventricose, $60-70 \times 19-22 \mu$

On naked earth. Finland.

decipiens, Bres., Fung. Trid., ii, p. r3, tab. cxviii ; Sacc., Syll, xi, p. 6r.

$P$. convex, then expanded and umbonate, floccosely-silky, disc even then breaking up into squamules, ochre-cinnamon, 3-5 cm.; g. crowded, broad, ventricose, sinuate, adnexed, cinnamon; s. glabrous, pallid, slightly striate, stuffed, base minutely marginato-bulbous, $4-5 \mathrm{~cm}$; sp. irregularly oblong, slightly tuberculate, II-I $4 \times 6-8 \mu$; c. ventricose, 50-70 I $^{-2} 5 \mu$

Gregarious. Austria.

Allied to $I$. lucifuga.

cicatricata, Ellis and Everh., Journ. Myc, v, p. 25 (1889); Sacc, Syll. ir, p. 100.

P. broadly and obtusely conical or conic-campanulate, expanding to convex, densely grey fibrilloso-rimose except the smooth disc, which is livid when moist, 2-2.5 cm.; g. ascending, adnexed with a slight decurrent tooth, becoming subsinuate and brownish-cinnamon; s. short, stout, sub-bulbous, solid, nearly white, tomentose, then darker, $I \cdot 5-3 \mathrm{~cm}$; sp. very irregularly and coarsely nodulose, usually more or less elongated, $10-12 \times 7-8 \mu$; c. broadly fusoid, not abundant, $45-55 \times 12-15 \mu$

Gravelly sand near filbert-trees. United States (Newfield, N.Y.).

Rather close to $I$. Renneyi.

Ellis gives the spore measurement as $7-9 \times 5^{-6} \mu$, but in the specimen quoted below I find them larger.

(Ellis and Everh., N. Amer. Fung. Ser. ii, r gor, examined.)

infida, Massee ; $A g$. (Heb.) infidus, Peck, 27 Rep. State Mus., p. 95 (1874); $A g$. umbratica, Quél., Assoc. Fr. 1883, tab. 6, f. 7 ; Sacc., Syll. v, p. 787 ; 1. Leucocephala, Boud., Soc. Bot. Fr. 1885 , tab. 9, f. 1 ; Sacc., Syll. v, p. 765 ; I. commixta, Bres., Fung., Trid., i, p. 53, tab. 48, f. 2 ; Sacc., Syll. v, p. 787 .

Entirely white. P. conico-campanulate then expanded and umbonate, silkyfibrillose, or more or less squamulose, white, or slightly tinged with grey or yellow, margin often splitting, $\mathbf{I} \cdot 5-3 \mathrm{~cm}$; g. free, crowded, greyish-cinnamon; s. solid, minutely pruinose, apex scurfy, white, $3-5 \mathrm{~cm}$.; sp. irregularly globose-oblong,

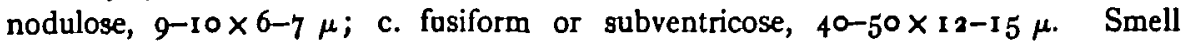
earthy, strong.

On the ground in woods, \&c. United States, France, Austria.

Superficially indistinguishable from the white form of $I$. geophylla, from which $\mathrm{K} \mathrm{k}$ 
the present species differs in the nodulose spores. Probably widely distributed, but passed over as I. geophylla. The pileus varies from silky-fibrillose to squamulose.

(Peck's type examined.)

trechispora, Karst., Hattsv., p. 465 ; Sacc., Syll. v, p. 789 ; Ag. (Ino.) trechisporus, Berk., Outl., p. 156, tab. 8, f. 6: Cke., Ill., pl. 403 A ; Ino. paludinella, Sacc., Syll. v, p. 788 ; Ag. (Ino.) paludinellus, Peck, 31 Rep. State Mus., p. 34 (1878).

' $P$. convex, then almost plane and umbonate, viscid at first then dry and silky, pallid or whitish, umbo often tinged ochre, $1 \cdot 5-2.5 \mathrm{~cm}$; g. emarginate, whitish then greyish cinnamon; s. equal, pallid, often slightly flexuous, with a mass of white mycelium at the base, $3-5 \mathrm{~cm}$; 8p. irregularly oblong, nodulose, $7-8 \times 5^{-6} \mu$; c. fusoid or subventricose, stout, fairly abundant, $40-50 \times 12-18 \mu$

In woods in damp places. Britain, United States (Sandlake), and ' $55 \mathbf{I}^{3}$, C. Wright, Con.,' in Herb. Kew.

Somewhat-resembling ' $I$. geophylla, differing in the nodulose spores. Peck's Fungus agrees beautifully with Berkeley's in all essential features. Cooke's fig. 9, I. Irechispora, is copied from Berkeley's original sketch, but the umbo is too dark, and the mass of white mycelium is not sufficiently emphasized in the reproduction. Saccardo's spore measurement of the spores-14-15 $\times 5^{-7} \mu$-is wrong, and has been copied from some one who has mistaken the species.

(Berkeley's and Peck's types examined.)

** Stem coloured.

fasciata, Sacc., Syll. ix, p. 95 ; Ag. (Ino.) fasciatus, Cke. and Massee, Grev., xvii, p. 52 ; Cke., Ill., pl. I 173.

P. campanulato-convex, silky, disc rufous the remainder pale tan, everywhere covered with minute dark squarrose scales, $5-7 \mathrm{~cm}$; g. adnexed, rounded or sinuate, narrowed in front, crowded, pallid; 8. equal or slightly narrowed downwards, fibrillose, reddish within and without at the base, pallid above, solid, 5-7 cm.; sp. irregularly elliptical, minutely nodulose, $10 \times 6 \mu$; c. ventricose, scanty, $40-50 \times$ I 2-I $5 \mu$.

On the ground among grass. Britain.

Densely caespitose, a feature which distinguishes the present from any other known species of Inocybe.

(Type examined.)

lanuginosa, Karst., Hattsv., p. 454 ; Ag. lanuginosus, Bull., Champ. Fr., tab. 370 ; Ag. (Ino.) lanuginosus, Fries, Syst. Myc., i, p. 257 ; Ag. sabuletorum, Berk. and Curtis, Grevillea, xix, p. 103; Ino. sabuletorum, Sacc., Syll. v, p. 765 .

P. convex, then expanded, obtuse, velvety, the pile becoming matted together into little squamules which stand erect at the disc, umber or brown then yellowish, I-z cm.; g. sinuate or free, thin, ventricose, becoming clear brown, edge white, minutely fimbriate; s. solid, slender, fibrillosely squamulose or downy, brown, apex white and mealy, $2-3 \mathrm{~cm}$.; sp. irregularly oblong, apiculate, with somewhat acute warts, $9-\mathrm{I} 2 \times 8 \mu$; c. fusoid, not very prominent, scattered, $40-50 \times 13^{-1} 5 \mu$

On the ground in woods, \&c. Britain, France, Austria, Russia, Sweden, Holland, United States (' Rav. No. I239, Car. Inf.,' in Herb. Kew. under I. lanuginosa, and $\boldsymbol{A g}$. sabuletorum, B. and C.). Sandy pine woods, Car. (M.A.C.). 
This species, as defined above, is the form accepted by European mycologists generally, and is represented in Roumeg., Fung. Gall., exs. 3814. In Brit. FungusFlora, ii, p. 183 , the spores are incorrectly said to be smooth.

(Berkeley's type of $I$. sabuletorum examined.)

maritimoldes, Peck, 38 Rep. State Mus., p. 87 ; Sacc., Syll. v, p. 77 I.

P. subconic or convex, dry, obtuse, densely squamulose, scales erect or fibrillose, minute, edge fibrillose, dusky brown, $\mathbf{I}-2.5 \mathrm{~cm}$.; g. adnate, rounded behind, ventricose, whitish then brownish-ochre; s. equal, solid, fibrillose, paler than p., $2.5 \mathrm{~cm}$; sp. ovate-oblong, very slightly nodulose, some practically smooth, $5^{-6} \times 4.5-5 \mu$; c. ventricose, $3^{6-45} \times$ 10-1 $2 \mu$, scattered.

Under trees. United States.

(Peck's type examined.)

calospora, Quél., in Bres., Fung. Trid., i, p. 19, tab. 2 I ; Sacc., Syll. v, p. 773 ; I. rigidipes, Peck, 5 I Rep. State Mus., p. 289 (1897).

P. convex or campanulate, then expanded and umbonate, fibrillose with darker squamules at the disc, yellowish-brown or tawny grey, edge paler, $\mathrm{I} \cdot 5 \mathbf{- 2 . 5} \mathrm{cm}$.; $\mathrm{g}$. sinuate, almost free, tawny-ochre or brownish; s. slender, pale then reddish, or coloured like p., 4-5 cm.; sp. globose, with numerous rather long, slender, cylindrical papillae, 10-1 $2 \mu$; c. not numerous, subcylindrical or slightly fusiform, $45-55 \times$ I I-1 $4 \mu$.

On the ground in woods and shady places. France, Britain (Wothorpe), United States (Menands, Albany Co.).

Peck noted the affinity of his species with $I$. calospora, but pointed out that the colour of his Fungus differed in being tawny grey. The two however appear to belong to the same species. The spores and cystidia are identical.

(Type of Peck's species examined.)

stellatospora, Mass. ; Ag. (Hebeloma) siellaiosporus, Peck, 26 Rep. State Mus., p. 57 ; Sacc., Syll. v, p. 798.

P. convex, rough with numerous squarrose scales, brown, $2.5 \mathrm{~cm}$.; g. pallid. then brown; s. equal, scaly, colour of p., $5 \mathrm{~cm}$.; sp. subglobose, rather coarsely nodulose, $7-8 \mu$; c. broadly fusiform, tapering into a long, slender pedicel, thin-walled, $70-80 \times 14-20 \mu$.

On the ground in woods. United States (Croghan).

Bears a close resemblance to $I$. mutata, but the persistent scales and rough spores distinguish it (Peck).

(Peck's type examined.)

putilla, Bres., Fung. Trid., p. 81, tab. 88; Sacc., Syll. ri, p. 50 (written pusilla).

$P$. conico-campanulate, then expanded and umbonate, fibrillosely-silky, then becoming torn into cracks, clay-colour or greyish-brown, or fuscous becoming pale, margin persistently lurid whitish, $1 \cdot 5-3 \mathrm{~cm}$.; g. somewhat crowded, sinuato-adnate, whitish then greyish-tan, edge crenulate; $s$. stuffed, very faintly tinged rose, white-. fibrillose becoming glabrous, apex white scurfy, $3-4.5 \mathrm{~cm}$; veil white, very evident

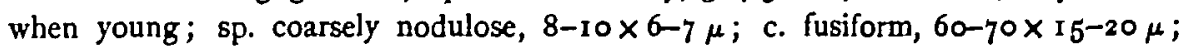
flesh of stem tinged rose. Smell strong, earthy.

On the ground under hazel, \&c. Austria.

Allied to $I$. perbrevis.

K $k 2$ 


\section{Massee.-A Monograph of the genus Inocybe, Karsten.}

Gaillardi, Gillet, Rev. Myc., v, p. 31 (1883); Gill., Champ. Fr., Hymen, a fig.; Sacc., Syll. v, p. 773; Pat., Tab. Anal., p. 11, f. 8 ; subfulva, Peck, 4 I Rep. State Mus., p. 66 (1888); Sacc., Syll. ix, p. 96 ; Ino. echinocarpa, Ellis and Everh., Journ. Myc., v, p. 25 (1889); Sacc., Syll. ix, p. 95.

$P$. conico-campanulate, then expanded and umbonate, pilosely-squamulose, the disc bristling with larger and stronger scales, tawny-yellow to rusty, $1-2 \mathrm{~cm}$. $\mathbf{g}$. nearly free, ventricose, broadish, rather. crowded, brownish-cinnamon, edge whitish; 8. slender, fibrillose, about colour of p., $1 \cdot 5-3 \mathrm{~cm}$; sp. subglobose or very slightly elongated, covered with long, slender spines, Io-1 $2 \times 8-9 \mu$; c. scanty, not very prominent, subcylindrical, $40 \times 9-12 \mu$.

On the ground under trees, \&c. France, United States.

Readily distinguished by the nature of the spores, which are sparsely covered with long, very slender, pointed spines, and the disc of the pileus with squarrose scales. The cystidia are rare, and apt to be overlooked.

This species appears to be not uncommon in the United States, for in addition to having been collected by Peck and Ellis, it is present in the Kew Herbarium, under I. trechispora, 'Rav., 2845 , Car. Inf.' ; under I. lacera, 'Rav., I588, Car. Inf.'; also under $I$. lacera, ' C. Wright, 5526, Connecticut.'

(Type from Peck of $I$. subfulva, also $I$. echinocarpa, in E. and E., N. A. Fung., ser. 2, no. I904, examined.)

Trinil, Karst., Hattsv., p. 463 ; Sacc. Syll., v, p. 781 ; Mass, Brit. FungusFlora, ii, p. I97; Ag. (Ino.) Trinii, Fries, Hym. Eur., p. 233 ; Cke., Ill., pl. 428 в. Ag. Trinit, Weinm., Hym.- et Gastero-mycetes Ross, I836, p. I 94.

$P$. hemispherical, obtuse, whitish with a rufous tinge, due to longitudinal rufous fibrils, tawny when dry, $1-2 \mathrm{~cm}$; g. rounded behind and adnexed, ventricose, dusky, cinnamon, edge white-flocculose; s. equal, stuffed, covered with loose reddish or rufous fibrils, apex with white meal, 4-6 cm.; sp. subglobose or somewhat oblong, nodulose,

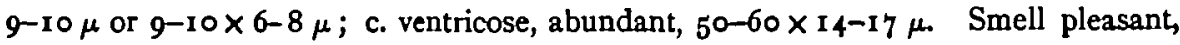
strong, resembling that of clove-pinks.

Among grass. Russia, Britain.

My conception of $I$. Trinii is as described above, and as figured by Cooke, 1. c., which agrees well with Weinmann's diagnosis. The fragrant, strong, clove-pink odour was very strongly marked in the fresh plants from which Cooke's figures.were drawn, and persists for some time after drying.

No species of Inocybe appears to be so little understood among mycologists as the present species. This I attribute to their not being conversant with Weinmann's own description of his plant, which is as follows :-

'A. Trinii Weinm. Pileo carnoso-membranaceo, hemispherico, albido, rufescentefibrilloso, obtuso; lamellis rotundatis, adfixis, obscure cinnamoneis, margine alboflocculosis; stipite aequali, farcto, rutilante-fibrilloso, apice albo-pulverulento.

'Solitarius. Odor valde suavis et fere caryophyllaceus 1-

'Pileus $\frac{1}{2}$ ' et paulo ultra lat longitudinaliter fibrosus. Lamellae $a^{\prime \prime}$ fere latae. Stipes $2-z^{\prime}$ long., $\mathbf{I}-\mathbf{r} \mathbf{z}^{\prime \prime}$ cras, fibrillis longitudinalibus obsitus. Sporidia sordide ferruginea.'

From this description it will be gathered that the Fungus is quite small, even for 
an Inocybe. No reference is made to the plant becoming red when broken, as insisted upon by other people.

I. Trinii, Weinm., Bresadola, Fung. Trid., ii, p. 14, tab. I20, with a whole string of synonyms, and with 'odore forti terreo' and smooth spores, is I. Godeyi, Gill.

maritima, Karst., Hattsv., p. 457 (1879); Sacc., Syll. v, p. 77 I (1887); Ag. (Ino.) maritimus, Cke., Ill., pl. $39^{2}$; Ag. maritimus, Fries, Obs. Myc., ii, p. $4 \mathbf{r}$ (1818).

P. hygrophanous, convex then almost plane and umbonate, flocculosely fibrillose, subsquamulose, brownish mouse-colour or umber; paler and hoary when dry, 2-2.5 $\mathrm{cm}$.; g. rounded and adnexed, then almost or quite free, broadish, grey then rusty; $\mathbf{s .}$ solid, equal, straight, fibrillose, slightly paler than p., apex naked, $1 \cdot 5^{-2 \cdot 5} \mathrm{~cm}$.; sp. irregularly oblong, apiculate, nodulose, Io-I I $\times 7-8 \mu$; c. ventricose, $45-55 \times$ I 2-18 $\mu$, not uncommon.

Often caespitose. Damp sand on sea-shore, also on ground in woods. Sweden, -Britain, Germany, Solomon Islands (Dr. Guppy).

Distinguished by the umber hygrophanous pileus becoming pale and hoary when dry. Allied to $I$. lanuginosa.

(Specimen from Fries examined.)

umbrina, Bres., Fung. Trid., i, p. 50, pl. 55 ; Sacc., Syll. v, p. 772.

P. convexo-campanulate, becoming almost plane and umbonate, chestnutbrown, somewhat viscid, fibrillosely woolly, then beautifully rimose, disc sometimes verruculose, $2-3.5 \mathrm{~cm}$; g. sinuato-adnate, crowded, dingy citrine, then rufouscinnamon, edge darker; s. stuffed, then partly hollow, equal, base slightly bulbous, fibrillose, somewhat paler than p., apex obsoletely white-scurfy, $4-6 \mathrm{~cm}$; sp. globose or irregularly oblong, coarsely nodulose, $7-8 \times 5-6 \mu$; c. ventricose, $60-70 \times 14-18$. Greyish-brown veil very evident in the young plant.

Gregarious or subcaespitose in pine woods. Austria.

When young resembling $I$. carpta, and when old resembling $I$. asterospora, but distinct from both (Bres.).

umboninota, Peck, $3^{8}$ Rep. State Mus.; Sacc., Syll. v, p. 780.

P. broadly campanulate or expanded, prominently umbonate, rimoso-fibrillose, dusky brown, 3-5 cm.; g. whitish, then rusty brown; 8 . equal or the base very slightly thickened, solid, fibrillose, paler than the pileus, apex pruinose, $3-3.5 \mathrm{~cm}$.; 'sp. irregularly oblong, very slightly nodulose, $6 \times 4.5-5 \mu$; c. very slightly ventricose or subcylindrical, 50-60 $511-14 \mu$, abundant.

On the ground among moss in woods. United States (Caroga).

Differs from $I$. rimosa in the nodulose spores, and from $I$. asteraspora in the very prominent umbo and different spores.

(Peck's type examined.)

rufoalba, Sacc., Syll.v, p. 787 ; Ag. (Ino.) rafoalbus, Pat. and Doass., Rev. Myc., 1886, p. 26 ; Pat. Tab. Anal., fig. 548 (1886).

P. convex, umbonate, brown, covered with a delicate white silky tomentum, which gives to the pileus a white appearance, except the umbo, which is always brown, up to $\mathrm{I} \mathrm{cm}$. ; $\mathrm{g}$. almost free, reddish-brown ; s. slender, equal, reddish, covered 


\section{Massee.-A Monograph of the genus Inocybe, Karsten.}

everywhere with a white silkiness that hides the colour, $\mathrm{r}-3 \mathrm{~cm}$.; sp. irregularly oblong, nodulose, $9-10 \times 4-5 \mu$; c. ventricose.

On the ground. France.

Allied to $I$. scabella.

Renneyi, Sacc., Syll. v, p. 788 ; Ag. (Ino.) Renneyi, B. and Br., Ann. Nat. Hist., no. 1761 ; Cke., Ill., pl. 520 A.

P. hemispherical, slightly fibrillose, disc brown, remainder pale fawn-colour, $1.5^{-2} \mathrm{~cm}$. ; g. rounded behind and almost free, dingy ochraceous; s. slightly narrowed downwards, fibrillose, solid, paler than p., 3-5 cm.; sp. angularly oblong, slightly nodulose, one end pointed, $1 \mathrm{I}-\mathrm{I} 3 \times 7-8 \mu$; c. rather thin-walled, fusoid, $40-50 \times$ i $2-$ $16 \mu$, much scattered and apt to be overlooked.

On the ground. Britain.

Allied to $I$. cicatricata, an American species.

(Type specimen examined.)

Var. major, Cke., Ill., pl. 520 в.

Coloured like the typical form, but larger; p. campanulate, up to $2.5 \mathrm{~cm}$.; g. broadly adnate, cinnamon colour; s. equal; sp. slightly nodulose, $13-17 \times 10_{\mu}$; c. as in the typical form.

In fir woods. Britain.

(Type examined.)

subexilis, Peck, $3^{8}$ Rep. State Mus., p. 87 ; Sacc., Syll. v, p. $7^{85}$.

$P$. convex or subcampanulate, then expanded and umbonate, edge fibrillose, at first pale chestnut, then yellowish or subochraceous, up to $1 \mathrm{~cm}$.; g. narrow, rather crowded, rounded behind, subventricose, whitish then subochraceous; s. solid, flexuous, slightly pruinose, rosy-white then yellowish, slightly striate, about $2 \mathrm{~cm}$.; sp. subglobose, slightly nodulose, 6 or $6 \times 5 \mu$; c. slightly ventricose, numerous, $45-60 \times 12-15 \mu$.

Mossy ground in woods. United States (Caroga).

(Peck's type examined.)

fulvella, Bres., Fung. Trid., ii, p. I6, tab. cxix, f. 2 ; Sacc., Syll. xi, p. 5 I.

P. subhygrophanous, conico-campanulate then expanded and umbonate, floccosely silky, disc glabrous, tawny, remainder at first yellowish olive, then yellowish or brownish olive, 6-12 mm.; g. rather distant, ventricose, pale lilac then ochraceous cinnamon, edge fimbriate, rounded behind and nearly free; s. stuffed, narrowed downwards, glabrous, apex white-pruinose, lilac then rufescent, $2-2.5 \mathrm{~cm}$. ; sp. irregularly oblong, tuberculose, $8-9 \times 5^{-6 \mu}$; c. ventricose, 45-60 $412-18 \mu$. Flesh yellow, rufescent-lilac at apex of stem.

Shady ground. Austria.

Allied to $I$. scabellus, which differs in having smooth spores.

\section{Cystidia absent.}

Ignobllis, Sacc. Syll. xi, p. 50; Ag. (Heb.) ignobilis, Berk., Lond. Journ. Bot., i, p. $45^{2}(1842)$.

P. glabrous, silky, plane or slightly depressed at the centre, rufous-brown, I.5-2 cm. ; g. sinuate, adnexed, and with a decurrent tooth, broad, rusty; s. incurved, 
equal, solid, glabrous, paler than p., 4-5 cm.; sp. irregularly oblong, nodulose, I I $-12 \times 8-9 \mu$; c. wanting.

On the ground. New Ireland.

One of the very few species having nodulose spores and no cystidia.

(Berkeley's type examined.)

margarispora, Sacc., Syll. v, p. 781 ; Ag. (Ino.) margarispora, Berk. ms. in Cke., Hdbk., ed. ii, p. I 57 ; Cke., Ill., pl. 5०5.

P. campanulate, then expanded and broadly umbonate, often flexuous, silky, clad with adpressed fibrillose scales, fawn-colour or pale yellowish-brown; $3-5 \mathrm{~cm}$.; g. adnexed, pallid ; s. solid, equal, fibrillose, pallid ; sp. subglobose, coarsely nodulose, 8-9 $\mu$; c. absent.

On the ground. Britain.

Resembles $I$. asterospora in general appearance and in spore characters, but differs in the absence of cystidia. I. eutheles differs in the smooth spores.

(Type specimen examined.)

Bucknalli, Massee (sp. nov.).

P. campanulato-convex, fibrillose, with a few squamules near the disc, brownish, I-a cm.; g. adnexed, thick, rather distant, rusty-brown, edge minutely fimbriate; -8. equal or slightly thickened at the base, slender, fibrillose, brownish, 2-4 cm.; sp. irregularly oblong, one end obliquely apiculate, rather coarsely nodulose, $1_{5}-$ I $7 \times 8-9 \mu$; c. absent; basidia clavate, exceptionally large, 70-80 $16-18 \mu$, 4-spored.

On the ground under bushes. Britain (Leigh Down, Bristol. Cedric Bucknall).

A little insignificant-looking brown Fungus, without any marked external characteristics, but at once distinguished by the size of the basidia, which are more than twice the size of those of any other known species. The spores and periphyses are also exceptionally large.

The fimbriate edge of the gills is due to the presence of numerous large thinwalled clavate cells about $75-85 \times 15-20 \mu$. These differ in structure from the cystidia, which spring from the sides and not from the edge of the gills.

\section{Spores rough, no knowledge of cystidia.}

*. Stem whitish or pallid.

grammata, Quél., Soc. Sci. Nat. Rouen, 1879, tab. 2, f. 8 ; Sacc., Syll. v, p. 781 .

P. campanulate, fibrous then splitting, cream-white then bistre or buff, $5-6 \mathrm{~cm}$, flesh white; s. bulbous, striate, tomentose, white, then like the flesh, assuming a rosy tint, $5^{-7} \mathrm{~cm}$. ; g. adnate, greyish then yellowish cinnamon; sp. elongated, nodulose, Io $\mu$ long.

Sandy ground under birches. France.

albipes, Gillet, Tab. Anal. Hymen., p. 113 (1884); Sacc., Syll. v, p. 780.

$P$. conical then campanulate, at length nearly plane and mammilate, longitudinally fibrously cracked, dingy yellow, centre darker, edge wavy and splitting when old, 4-5 cm.; g. free, ventricose, crowded, thickish, yellowish-white then 


\section{Massee.-A Monograph of the genus Inocybe, Karsten.}

brownish ; s. entirely white, squamulose, stuffed, firm, striate, $6-8 \mathrm{~cm}$. ; sp. irregularly nodulose. Flesh white.

On the ground. France.

** Stem coloured.

asinina, Kalchbr., Icon. Hym. Hung., p. $3^{8}$, pl. xxii, fig. I (1873); Sacc., Syll. v, p. $77 \mathrm{r}$; Ag. (Ino.) asininus, Kalchbr., in Fries, Hym. Eur., p. 230.

P. convex then plane, subgibbous, dry, adpressedly fibrillose, hoary, at length rufous-tan, 3-6 cm.; g. adnate, becoming distinctly sinuate, rather crowded, broad, yellowish-grey then dusky cinnamon, edge paler; s. solid, subventricose, or equal in small specimens, attenuated upwards, generally twisted, brownish-tan, fibrillose from the lax veil, annular zone fairly persistent, becoming umber. from the spores, about $5 \mathrm{~cm}$.; sp. subglobose, nodulose.

On the ground. Gregarious or subcaespitose. Hungary, Holland.

radiata, Peck, Bull. Torr. Bot. Club, xxii, p. $4^{88}$ (1895); Sacc., Syll. xiv, p. I33.

P. convex or subcampanulate, distinctly umbonate, silky-fibrillose; slightly rimulose, distinctly radiately wrinkled when dry, yellowish-brown, umbo darker, : 2-5 cm.; g. emarginate, rather broad, crowded, brownish becoming tawny-cinnamon, edge whitish; s. equal, solid, almost glabrous, a little paler than p., $\dot{3}-5 \mathrm{~cm}$.; sp. subovate, slightly nodulose or angular, 10-1 $3 \times 5^{-6 \mu}$.

Open grassy ground. .United States (Mass.).

The radiations of the pileus are not noticeable in the fresh plant (Peck).

I have not seen a specimen of this species, which appears to depend for its distinctness mainly on a character not present in the living plant.

\section{B. SPORES SMOоTH,}

\section{* Stem whilish or pallid.}

\section{Cystidia present.}

+ Gills brownish, ockraceous, or cinnamon.

hirtella, Bres., Fung. Trid., i, p. 52, tab. lviii, f. 1 ; Sacc., Syll. v, p. 770.

P. conico-campanulate, then expanded and umbonate, margin soon splitting, yellowish straw-colour, with numerous darker pilose squamules, disc glabrous, 1.5-2.5 cm.; g. adnate, rather crowded, brownish, edge white-pruinose; s. stuffed, white then tinged straw-colour, slightly narrowed downwards, white-plumulose under a lens, with a minute subterranean bulb, 2-4 cm.; sp. pip-shaped, smooth, 10-12 $\times 6 \mu$; c. fusoid, $60-70 \times 12-15 \mu$.

On the ground. Austria.

Quélet (Fl. Myc., I05) considers this species to be a variety of $I$. lucifuga, from which it only differs in the straw-coloured pileus with darker squamules and brown gills. Spores and cystidia are the same in both.

scabra, Karst., Hattsv., p. 457 (1879); Sacc., Syll. v, p. 767; Ag. (Iro.) scaber, Fries, Hym. Eur., p. 228 ; Cke., Ill., pl. 391 ; Ag. scaber, Mull., Fl. Daw., v, fasc. xiv, p. 7, tab. $83^{2}$, f. $3(1782)$; Low., Eng. Fungi, pl. 207.

P. broadly conical, often subgibbous, dusky or pale yellowish tan, variegated with fbrous, adpressed darker scales, $1.5-3 \mathrm{~cm}$.; $\mathrm{g}$. adnexed, somewhat crowded, 
pale then dusky or brownish; s. stout, short, equal, slightly thickened at the base, .solid, whitish, distinctly cortinate, silky-fibrillose, $2-3 \mathrm{~cm}$.; sp. pip-shaped, smooth, 9-I I $\times 5-6 \mu$; c. slightly ventricose, $65-75 \times$ I 2-16 4 , abundant. Flesh white, not changing colour.

On the ground in coniferous and mixed woods. Britain, France, Germany, Sweden, Denmark, Holland.

The above agrees with the species as understood by Fries, and represented as I. scabra in Roum., Fung. Gall., exs. 1902, and Rabenh., Fung. Eur. I902.

This Fungus is much more sturdy and with a thicker stem than other allied species. The species may practically be considered as originating with Fries, for .although he quoted Maller's figure and adopted his name, there is really nothing to prove that the species accepted by Fries was the plant so named by Maller, whose brief description is as follows:-

'Agaricus scaber lamellis et stipile albis, pilea hemispherico fusco, squamoso.'

Muller's figure represents a group of quite young specimens, and does not suggest anything very definite.

pyriodora, Karst., Hattsv., p. 456; Sacc., Syll. v, p. 766 ; Cke., Ill., pl. 472 ; Bres., Fung. Trid., tab. lii ; Agaricus pyriodorus, Pers., Syn., p. $3^{\circ 0 .}$

$P$. ovate, then campanulate, at length expanded and umbonate, pale ochre, sometimes reddish when young, $4-7 \mathrm{~cm}$.; g. adnate then rather rounded behind, thin, crowded, brownish, edge whitish; s. solid, nearly equal, often curved near the base, fibrillose, pallid, apex with white meal, flesh reddish when cut; sp. pip-shaped, apiculate, smooth, 9-10 $\times 5^{-6 \mu}$; c. variable in form, ventricose or clavate, 40-50 $\times$ I $^{-1} 7 \mu$, scattered. Smell pleasant, resembling ripe pears.

In woods. Britain, France, Germany, Austria, Sweden, Russia, Finland, United States (Waynesville, Ohio, T. G. Lea, 1844).

Odour penetrating, like that of rotten pears or Hyacinthus racemosus (Berk.).

The above diagnosis accords with what is universally accepted by mycologists as the species of Persoon.

rimosa, Karst., Hattsv., p. 462 ; Sacc., Syll. v, p. 775 ; Ag. rimosus, Bull., Champ. Fr., tab. $3^{88}$; Ag. (Ino.) rimosus, Cke., Ill., pl. $3^{84}$.

P. campanulate, sometimes subumbonate, silky-fibrous and becoming cracked from disc to margin, yellowish-brown, $2 \cdot 5-5 \mathrm{~cm}$; g. almost free, somewhat crowded and ventricose, dingy tan; s. equal, firm, nearly smooth, whitish, apex mealy, $4-7 \mathrm{~cm}$; p. pip-shaped, smooth, 12-1 $5 \times 7 \mu$; c. ventricose, scattered, $60-65 \times 15-18 \mu$. Smell earthy. Holland.

On the ground in woods. Britain, France, Germany, Sweden, Russia, Finland,

Differs from I. asterospora and I. fastigiala in the smooth spores. I. eutheles is separated by the adnate gills and umbonate pileus, and $I$. pyriodora by the strong smell.

One of the old species about the identity of which practically all are agreed. It is represented in C. Roumeg., Fung. Sel., exs. 5306 ; Roumeg., Fung. Gall., exs. 1302 and $3^{81} 3$; Sydow, Myc. March, 2609.

subochracea, Massee; Ag. (Heb.) subochraceum, Peck, 23 Rep. State Mus., p. 95 (1870); Heb. subochraceum, Sacc., Syll. v, p. 796. 


\section{Massee.-A Monograph of the genus Inocybe, Karsten.}

P. conical or convex, sometimes expanded, generally umbonate, fibrillously squamulose, pale ochraceous, $2-3.5 \mathrm{~cm}$.; g. attached, emarginate, rather broad, whitish then brownish-yellow; 8. equal, whitish, slightly fibrillose, solid, $2.5-5 \mathrm{~cm}$. ; sp. pip-shaped, smooth, $8 \times 4.5-5 \mu$; c. ventricose, $45-60 \times 12-15 \mu$, fairly abundant.

On the ground in fields and by roadsides. United States (North Elba and West Albany).

(Type from Peck examined.)

cortinata, Roll., Bull. Soc. Myc., xvii, p. I I 7, pl. 3, f. I (Igor).

P. campanulate with a stout umbo, pale straw-colour, umbo rusty, at first minutely fibrilloso-striate then torn and deeper coloured, up to $4 \mathrm{~cm}$.; veil white, floccose, appendiculate; g. adnato-decurrent, ventricose, whitish then brownish-ochre, edge paler, floccoso-serrulate; s. stuffed, white, minutely fibrillosely striate, scurfy upwards, fragile; curved, flexuous, the imperfect ring fibrillose, white, median, cylindrical, base usually sub-bulbous, $6-8 \mathrm{~cm}$.; sp. pip-shaped, smooth, $8 \times 4-5 \mu$; c. ventricose.

Gregarious under pines. Belgium.

Differs from $I$. valricosa in the veil not being viscid. Perhaps a cortinate form of $I$. sindonia (Rolland).

eutheles, Sacc., Syll. v, p. 776 ; Ag. (Ino.) euthelus, B. and Br., Ann. Nat. Hist., I865, pl. viii, f. 2 ; Cke., Ill., pl. $3^{86 .}$

P. campanulate then expanded and strongly umbonate, shining, silky, rather squamulose, pale fawn-colour, $2.5-5 \mathrm{~cm}$. g. broadly and abruptly adnate, narrowish, pallid, edge whitish, denticulate; s. equal, slightly swollen at the very base, fibrous, solid, pallid or whitish, 4-8 cm.; sp. elliptical, smooth, 9-10 $\times 5-5.5 \mu$; c. fairly abundant, stout, ventricose, $60-65 \times$ I $_{5}-20 \mu$. Smell mealy.

On the ground among pine leaves. Britain, France.

I. pallidipes and $I$. eutheloides are closely allied to this species, which also bears a general resemblance to $I$. fastigiala, but differs in having smooth spores. The large upper figure and section.in Cooke's Ill. are copied from Berkeley's original drawing, the other figures on the plate are not authoritative.

(Berkeley's type examined.)

pallidipes, Ellis and Everh., Journ. Myc., v, p. 24 (1889); Sacc., Syll. ix, p. 96 .

P. conico-campanulate, then expanded and umbonate, light brown, fibrosesquamose, disc innately scaly, margin subrimose, 2-3 cm.; g. broadly attached with a strong decurrent tooth, ascending at first then ventricose, scarcely crowded, rather broad, pale cinnamon, edge paler and fimbriate; s. white, slightly narrowed and mealy above, loosely fibrillose below, sub-bulbous and with white tomentum at the base, solid, 2.5-5 cm. ; sp. pip-shaped, smooth, 8-9 $\times 5 \mu$; c. fusoid or subventricose, numerous, $40-50 \times 14-18 \mu$.

On the ground under filbert-trees. United States (Newfield, N.Y.).

The disc of the pileus is carnose, and in wet weather rimose-squamose. Well marked by its conic-campanulate pileus and white stem, which remains white till the plant withers (E. and E.). 
Very near to $I$. eutheles, if indeed distinct. Differing mainly in the broader gills having a strong ecurrent tooth. Also allied to $I$. cutheloides.

(Specimen in Ellis and Everh., N. Amer. Fung., ser. ii, a ro2, eramined.)

sambacina, Sacc., Syll. v, p. 782 ; $A g$. (Ino.) sambucinus, Fries, Syst. Myc., i, p. 257 (1821); Fries, Icon. Sel., tab. 109, f. 2 ; Cke., Ill., pl. 399.

P. convex then expanded, obtuse or subumbonate, often wavy, silky-fibrillose, nearly glabrous and not cracking, white, often becoming tinged yellow, $5-8 \mathrm{~cm}$.; g. emarginate, slightly adnexed, broad, ventricose, whitish then dingy ochre; s. stout, short, often curved, equal or thickened at the base, fibrillosely striate, white, solid, $2.5-3.5 \mathrm{~cm}$; sp. elliptical, smooth, $9-12 \times 6 \mu$; c. scattered, ventricose, $5^{0-60} \times 12-$ $16 \mu$. Smell strong.

Solitary. In dry pine woods, \&c. Britain, France, Germany, Sweden.

A stout Fungus, entirely white, the pileus often becoming yellowish with age. I. sindonia differs in the narrow gills, stuffed then hollow stem, and smaller spores.

Clarkii, Sacc., Syll. v, p. 784 ; Cke., Ill., pl. 429 в.

$P$. campanulate, obtuse, whitish, silky-fibrillose, $2-3 \mathrm{~cm}$; g. adnexed, rather distant, broadish, pallid, margin white; s equal or slightly thickened at the base, solid, white, 3-5 cm.; sp. elliptical, smooth, 8-10 $\times 5-6 \mu$; c. scattered, ventricose, $55-65 \times 12-16 \mu$, some thinner.

On the ground in shady places. Britain.

Allied to $I$. sindonia, but separated by the solid stem, persistently pale gills, and larger spores.

(Type specimen examined.)

corydalina, Quél., Jur. et Vosg., iii, p. i I 5 ; Soc. Bot. Fr., xxiv, t. 5, f. 10 ; : Sacc., Syll. v, p. 766 .

$P$. campanulate then expanded, fibrillose, white, the prominent umbo glaucousgreen, 4-6 cm.; g. adnate, emarginate, brown, edge white ; s. fragile, white; sp. pipshaped, smooth, 8-10 $\times 5 \mu$; c. ventricose, 50-60 $\times 12-15 \mu$. Smell strong, like Corydalis cava. Flesh white, sometimes tinged lilac.

Woods. France.

(Specimen from Quélet examined.)

Var. roseola, Pat., Ann. Tab. Fung., no. 553.

Pileus entirely green; flesh tinged rosy when cut.

France.

geophylla, Karst., Hattsv., p. 464 ; Sacc., Syll. v, p. 784 ; Ag. (Ino.) geophyllus, :Fries, Epicr., p. I76; Cke., Ill., pl 401.

P. conical then expanded and umbonate, minutely fibrillose, satiny and shining, often cracking, pure white, sometimes tinged yellow when old, $1 \cdot 5-3 \mathrm{~cm}$.; $\mathrm{g}$. almost free, rather broad, ventricose, crowded, pale then becoming dingy clay-colour; s. stuffed, satiny, apex minutely floccose, white, equal, base slightly thickened, often rather flexuous, 4-7 cm.; sp. elliptical, slightly apiculate, smooth, 7-9 $\times 4-5 \mu$; c. fairly abundant, ventricose, $45^{-60} \times 10-16 \mu$. Smell earthy.

On the ground in woods, \&c. Britain, Ireland, France, Germany, Sweden, Switzerland, Italy, Austria, Holland, Russia, United States. 


\section{Massee.-A Monograph of the genus Inocybe, Karsten.}

A very distinct and well-marked species, but at the same time very variable in the colour of the pileus, which ranges from pure white, the commonest form, to yellow, lilac, violet, tawny, and brick-red. Some of these colour-forms have been quite unnecessarily considered as varieties; as var. fulvus, Pat., Tab. Anal., n. 544 ; var. violaceus, Pat., Tab. Anal., n. 545. . The pileus is never truly squamulose.

One of the old species on which all mycologists, up to the present, are agreed. As defined above it is represented in the following exsiccati: Rab., Fung. Eur., 10; Thum., Myc. Univ., 2001 ; Thüm., Fung. Austr., r r 04; Desm., Crypt. France, 459 ; Desm., Crypt. France, ser. 2, 458 ; Sydow, Myc. March, 26 ro.

Whitei, Sacc., Syll. v, 790; $A g$. (Ino.) Whitei, B. and Br., Ann. Nat. Hist., no. 1,527; I. agglutinata, Peck, 4I Rep. State Mus., p. 65 ; Sacc., Syll. ix, p. 98.

$P$. conical then convex, sometimes umbonate, fibrillose, tawny, margin whitish, then wholly pale tawny, slightly viscid, $1 \cdot 5-2.5 \mathrm{~cm}$. ; g. adnexed, crowded, white then cinnamon; s. solid, nearly equal, base slightly thickened, whitish and pulverulent, becoming brownish downwards, 3-6 cm.; sp. pip-shaped, smooth, 9-I $1 \times .4-5 \mu$; c. fairly abundant, ventricose or almost cylindrical, $50-60 \times 16-20 \mu$.

On the ground under conifers. Britain, United States (Catskill Mts.).

Both Berkeley and Peck indicate the affinity of the present species with I. geophylla.

(Types from Berkeley and Peck examined.)

sindonia, Karst., Hattsv., p. 464 ; Sacc., Syll. v, p. 784 ; Ag. (Ino.) sindonius, Cke., Ill, pl. 400.

P. campanulato-convex, broadly umbonate, silkily downy when young, becoming almost glabrous, never fibrillose, when young the margin is appendiculate from the fibrils of the veil, white, pallid, or yellowish, $3-5 \mathrm{~cm}$; g. slightly adnexed, narrow, brownish white; 8 . soft, with a distinct pith then hollow, slightly fibrillose then glabrous, white, equal, $5-7 \mathrm{~cm}$; sp. pip-shaped, smooth, 8-10 $\times 5-6 \mu$; c. ventricose, $50-60 \times 12-16 \mu$

On the ground in damp, shady places. Britain, Germany, Sweden.

Resembling $I$. geophylla superficially; differing in the hollow stem, larger size, absence of earthy smell, \&c.

descissa, Karst., Hattsv., p. $4^{6} 3$; Sacc., Syll. v, 777 ; Ag. (Ino.) descissus, Fries, Epicr., p. I 74 ; Cke., Ill., pl. 428.

P. conico-campanulate then expanded, edge usually slightly incurved, fibrillose, becoming radiately rimose and splitting when expanded, whitish or pale dingy brown, I.5-2.5 cm.; g. almost free, somewhat crowded, white then brown; s. almost hollow, equal, often slightly wavy, fibrillose, white, apex with white meal, fragile, $2-3.5 \mathrm{~cm}$.; sp. elliptic-oblong, sometimes slightly curved, apiculate, smooth, 8-10 $5 \%$; c. ventricose, scattered, $50-60 \times 12-16 \mu$.

On the ground in woods. Britain, France, Sweden, Holland.

A small species somewhat resembling $I$. geophylla, differing in the colour of the pileus and absence of a strong earthy smell. I have accepted, as typical of this species, specimens determined by Berkeley and figured by Cooke (Ill., pl. 428, top figs.). The colour of the pileus is too bright in these figures.

Some authors give $\mathrm{Ag}$. auricomus, Batsch, as a variety of this species. I have 
not seen an authentic specimen, nor have $I$ at any time collected a Fungus that seemed to be the species intended by Batsch, whose own diagnosis I give.

' $A$. auricomus. Pileo luteo, lineis fuscis radiatim piloso; stipite lineari, valido, albo ; lamellis fusco-cinereis.' Batsch, Elench. Fung., r 783 , p. 75, tab. v, f. 2 I.

Batsch's figure represents a small Fungus, pileus $I \cdot 5 \mathrm{~cm}$. diam.; stem $2 \mathrm{~cm}$. long, and coloured brown like the pileus, although stated to be white in the description.

cervicolor, Quél., Flor. Myc., p. Io7; Ag. cervicolor, Pers., Icon. Pict. Rar. Fung., tab. 8, f. $4\left(180_{3}-1806\right)$.

P. campanulate, pale brown or fawn-colour, covered with brown, recurved fibrils, $3-5 \mathrm{~cm}$.; g. emarginate, ventricose, distant, pale then rusty brown, margin whitish, denticulate; s. elongated, slender, firm, whitish, fibrillose with brown recurved filaments throughout its length, 6-9 cm.; spores elongate pip-shaped, smooth, I I-I $3 \times 6-6.5$; c. cylindric-fusoid, numerous, $40-50 \times 12-18 \mu$. Flesh white, tinged purplish when cut. Smell strong, unpleasant.

Among grass in woods. Britain, France.

Quelet gives $I$. Bongardi as a synonym of the present species, which I think is not correct. I. Bongardi differs in the whitish mealy apex of the stem, arcuatoadnate gills, and different smell, which Weinmann says 'odor exacte ut in Pyro. com. var. "Bergamotte" dicta.' Quélet says of $I$. cervicolor 'odeur de tonneau moisi.'

(Specimen accepted as typical placed in Herb. Kew.).

deglubens, Karst., Hattsv., p. 459 ; Sacc., Syll. v, p. 769; Ag. deglubens, Fries, Epicr., p. I73; $A g$. (Ino.) deglubens, Cke., Ill., pl. 394.

$P$. convex then expanded and obtusely umbonate, the cuticle becoming broken up into adpressed fibres, disc more or less squamulose, brownish bay then yellowish, the fibres and squamules darker, $\mathbf{r} \cdot 5^{-2-5} \mathrm{~cm}$; g. adnate, subsinuate, ventricose, somewhat distant, greyish then cinnamon; s. solid, adpressedly fibrillose and almost glabrous, pallid, sometimes tinged lilac, apex slightly rough with brown points, 4-7 cm.; sp. 8-1 $0 \times 5-6 \mu$, pip-shaped, smooth; c. fairly abundant, ventricose, $50-60 \times 10-15 \mu$. Flesh white.

Finland.

On the ground in pine woods, \&c. Britain, France, Germany, Sweden,

Differs from $I$. lacera in the apex of the stem being darker than the remainder, instead of being white.and mealy.

Var. trivialis, Karst., Symb. Myc., ix, p. 43.

P. somewhat resembling in character the typical form, bat up to $5 \mathrm{~cm}$. across; 8. fibrillose then becoming glabrous, apex whitish, somewhat mealy, then becoming darker and somewhat rufescent both outside and inside; sp. cymbiform; 10-r 2 $\times 4-5 \mathrm{~cm}$.

Among grass. Finland.

infelix, Peck, 4I Rep. State Mus., p. 29; Sacc., Syll. ix, p. 96.

P. campanulate then convex or expanded and subumbonate; fibro-squamulose, greyish brown or umber, margin sometimes torn, $2.5 \mathrm{~cm}$; g. crowded, emarginate, ventricose, broadish, whitish then rusty-brown; s. equal, solid, pallid or whitish, apex white and pruinose, $2.5-5 \mathrm{~cm}$; sp. cylindric-elliptical, smooth, 11-13 $35 \mu$; 


\section{Massee.-A Monograph of the genus Inocybe, Karsten.}

c. fairly abundant, broadly ventricose, 40-50 $\times 14^{-20 \mu}$, some narrower and almost cylindrical.

Mossy ground. United States (Indian Lake).

(Type from Peck examined.)

t+ Gills with an olive tinge.

abjecta, Karst., Hattsv., p. $45^{6}$; Sacc., Syll. v, p. 768.

P. subcampanulate or convex then expanded, sometimes subumbonate, brownish, becoming ochraceous-brown when dry, everywhere covered with white fibrils, disc with whitish subsquarrose squamules, $1-2.5 \mathrm{~cm}$; g. adnate, rather distant, broad, ventricose in front, pale cinnamon-olive, margin minutely flocculoso-crenulate at first; s. solid, equal, rather tough, flexuous, pallid, everywhere covered with white fibrous squamules, apex white-pruinose, $3-4 \mathrm{~cm}$; sp. pip-shaped, smooth, ro-14 $\times 5$ $7 \mu$; c. scanty, ventricose, $45^{-6} 5 \times 12-15 \mu$. Flesh persistently white.

On naked ground near paths, \&c. . Finland, Sweden.

(Portion of type examined.)

destricta, Karst., Hattsv., p. 462 ; Sacc., Syll. v, p. 777 ; Ag. (Ino.) destrictus, Fries, Epicr., p. 174 ; Fries, Icon. Sel., tab. 108, fig. 3 ; Cke., Ill., pl. ${ }^{8} 7$; Ag. Bongardi, Kalchbr., Icon., tab. 2o, f. I.

P. convex then expanded, usually becoming depressed round the umbo, pallid then rufescent, cuticle with wide cracks showing the white under stratum, sometimes the cuticle is more or less broken up into fibrils or squamuies, $3-0 \mathrm{~cm}$.; 8 . uñincirately adnate, crowded, whitish then dusky cinnamon with an olive tinge; s. nearly equal, glabrous, fibrillosely striate, whitish, becoming reddish with age, aper slightly mealy, solid, 4-5 cm.; sp. pip-shaped or elliptical, smooth, 8-9 $\times 5^{-6 \mu}$; c. abundant, ventricose, $55^{-6} 5 \times 12-16 \mu$. Smell unpleasant.

On the "ground in pine woods, \&c. Britain, France, Germany, Sweden, Holland.

A large, well-marked species. The pileus becomes dark brown with age, especially the central portion.. The cuticle becomes quite rigid before the pileus attains its full growth, hence during increase in size of the pileus the rigid cuticle is much cracked and torn, exposing the white flesh.

The species as understood above is represented in Roumeg., Fung. Gall. Exs., $180 \mathrm{r}$.

concinna, Karst, Symb. ad Myc. Fenn., zxix, in Med. Soc. Faun. et Flor. Fenn., 1889, p. 29 ; Sacc., Syll. ix, p. 99.

P. convexo-plane, subumbonate, even, glabrous, innately fibrillose, rusty or pale brown, 2-3 cm.; g. sinuato-adnate, crowded, pale olive then rusty, edge paler and crenulate; s. solid, equal, flexuous, subfibrillose, pallid, apex white-pruinose, about $4 \mathrm{~cm}$; ; sp. pip-shaped, smooth, 8-1 $3 \times 5^{-6 \mu}$; c. ventricose-fusoid, 60-65 $\times 14^{-1} 7_{\mu}$.

In pine woods. Finland.

confusa, Karst., Symb. Myc. Fenn., xxviii, in Med. Soc. Flor. et Faun. Fenn., 1888, p. 39 ; Sacc., Syll. ix, p. ror.

$P$. conico-campanulate, then expanded and umbonate, glabrous, the cuticle breaking up into fibrils and slightly cracking, yellowish rusty or bay, up to $9 \mathrm{~cm}$; g. crowded, ventricose, yellowish then pale olive; s. solid, firm, almost 


\section{Massee.-A Monograph of the genus Inocjbe, Karsten. $48 \mathrm{I}$}

glabrous, pallid, up to $12 \mathrm{~cm}$. high and I $\mathrm{cm}$. thick, cylindrical; sp. elliptical or subreniform, ends very obtuse, smooth, $10-\mathrm{r} 2 \times 6 \mu$; c. inflato-clavate, $40 \times 14-18 \mu$.

In mixed woods. Finland.

Karsten queries the word cystidia, and from the shape given these structures occur only along the margin of the gill, and are not spread over its surface.

Godeyl, Gillet, Champ. Fr., Hymeno.; p. 517 (1874); Sacc., Syll. v, p. $77^{8}$; Ag. (Ino.) Trinii, Pat., Tab. Anal., n. 345 ; and Ag. (Ino.) Trinii, var. rubescens, n. 344 ; I. rubescens, Gill., Rev. Myc., v, p. $3^{\mathrm{I}}$ (1883); and Champ. Fr. Hymen. with plate, and described in the general index (1897); Sacc., Syll. v, p. 786 ; Ino. Trinii, Bres. (non Weinm.), Fung. Trid., ii, p. I4, tab. I20; Ino. repanda, Quél. (non Bull.), Flor. Myc., p. ror (r888); Ino. hiulca, Kalchbr., p. 33, tab. 20, f. 2; Sacc., Syll. v, p. 774.

P. campanulate, obtusely umbonate, silky-fibrillose, rimose, whitish at first then more or less suffused with a rosy tinge, which is usually accompanied by an ochraceous tinge, margin splitting, 3-5 cm.; g. narrowed behind and adnexed, almost free, somewhat crowded, whitish then dusky cinnamon, usually with an olive tinge, edge white, minutely flocculose; s. equal, slightly bulbous, colour of p., apex white-pruinose, 4-6 cm.; sp. elliptical, slightly curved or subreniform, smooth, $9-12 \times 5.5^{-6} \mu ;$ c. ventricose, $40-65 \times 15^{-20} \mu$, fairly numerous. Smell strong, unpleasant.

On the ground in woods, \&c. Britain, France, Germany, Austria, Hungary.

One of the larger species of Inocybe, characterized by the pileus and stem being either pure white, or nearly so, and silky when young. As the Fungus advances in age rosy-red or ochraceous-rosy stains appear on the pileus and stem. These tints are also produced when the plant is bruised.

Bresadola (Fung. Trid., ii, p. 14 ) agrees with me in considering all the species named above to belong to one species; our only difference turns on the determination of Ag. Trinii, Weinm., Bresadola considering that his $I$. Trinii is Weinmann's plant, whereas under what I have considered as Ag. Trinii in this work the reasons are given for not coinciding with this opinion.

(Specimens of Gillet's $I$. Godeyi and Quélet's 1 . repanda examined.)

lucifuga (Fries), Karst., Hattsv., p. 465; Sacc., Syll. v, p. $78_{3}$; Agaricus lucifugus, Fries, Obs. Myc., ii, p. 50 (1818); Cke., Ill., pl. 429 ^.

$\mathrm{P}$. convexo-campanulate, then expanded and more or less umbonate, longitudinally fibrillose or covered with minute adpressed scales, olive or brownish, rarely fawn-colour, often becoming pale, $x \cdot 5^{-2} \cdot 5 \mathrm{~cm}$; flesh whitish ; $\mathrm{g}$. nearly free, crowded, ventricose, white then yellowish, at length dark olive; s. solid, equal, almost glabrous, often subflexuous, pallid, apex white-farinose, $3-5 \mathrm{~cm}$.; sp. pipshaped, smooth, 9-10 $\times 5-6 \mu$; c. scattered, ventricose, $60-70 \times 12-14 \mu$. Smell strong, somewhat like radishes.

In pine woods, \&c. Britain, Sweden, France, Germany, Russia, Finland.

Distinguished by the deep olive gills, almost glabrous stem, and strong smell. I. hirlella is probably only a variety of this species.

(Specimen from Fries examined.) 


\section{Massee.-A Monograph of the genus Inocybe, Karsten.}

Glavella, Karst., Symb. Myc. Fenn., xxix, in Med. Soc. Flor. et Faun. Fenn, I889, p. I00; Sacc., Syll. ix, p. 100.

P. acutely conoid then expanded and acutely umbonate, innately fibrillosorimulose, glabrous, yellowish and somewhat shining, 2-3 cm.; g. adnexed, crowded, yellowish then olive, edge paler and crenulate; s. solid, equal, flexuous, white with a yellow tinge, apex white-flocculose, about $3 \mathrm{~cm}$.; sp. oblong, ends very obtuse, almost cylindrical, smooth, $12-14 \times 4^{-6 \mu}$; c. fasciculate, cylindrical, and apex clavate, sometimes ventricose, $60-90 \times 8-14 \mu$.

In pine woods. Finland.

H+ Gills tinged violet.

violaceifolia, Sacc., Syll. ix, p. 98; Ag. (Ino.) violaccifolius, Peck, 4I Rep. State Mus., p. 66.

P. convex or almost plane, fibrillose, subsquamulose, grey, $1-1 \cdot 5 \mathrm{~cm}$; g. crowded, adnexed, pale violet then brownish cinnamon; 8. firm, solid, slender, fibrillose, whitish, $2.5 \mathrm{~cm}$. long; s. smooth, elliptical, $10 \times 6.5 \mu$; ventricose, $50-60$ $\times 12-16 \mu$, fairly numerous.

Mossy ground in woods. United States (Selkirk).

Distinguished among species having the gills tinged lilac by the whitish stem.

(Peck's type examined.)

** Stem coloured.

+ Gills srowin, ochraceous or cinnamon.

caesariata, Karst., Hattsv., p. 459 ; Sacc., Syll. v, p. 783 ; Ag. caesariatus, Fries, Epicr., p. I76; Ag. (Inocybe) caesariatus, Cke., Ill., pl. $33^{8 .}$

$P$. convex then expanded, broadly subumbonate, tawny-ochraceous, densely covered with spreading ochraceous fibrils, which are sometimes collected into more or less concentric squarrose squamules, $2-3 \mathrm{~cm}$; g. adnexed, rounded behind, edge quite entire, pale ochraceous; s. equal, sometimes slightly wavy, solid, strongly loosely fibrillose, pale ochraceous, 4-8 cm.; sp. 8-10 $\times 4-5 \mu$, pip-shaped, smooth ; c. narrowly ventricose, fairly abundant, 70-80 $\times 12-15 \mu$.

In beech woods, \&c. Britain, France, Germany, Sweden.

The above diagnosis is drawn up from specimens examined by Fries in a fresh state, being sent by Berkeley. Cooke's figure in Ill., pl. $3^{83}$, is copied from Berkeley's original drawing of the specimens sent to Fries. The superficial fibrils are not well shown.

(Specimens determined by Fries examined.)

obscura, Karst, Hattsv., p. 460; Sacc., Syll. v, p. 770 ; Ag. obscurus, Pers., Syn. Fung., p. 347 (1801); Ag: (Heb.) abscurus, Saund., Sm. and Bennet, Myc. Ill., i, pl. 2 I, lower fig. (187 I).

P. campanulato-convex, obtuse or subumbonate, radially fibrillose, disc squamulose, brown more or less suffused with violet, $1 \cdot 5-2.5 \mathrm{~cm}$; g. adnexed, uncinate, crowded, ventricose, olive then brownish; s. elongated, stuffed, often slightly wavy, fibrillose, colour of p., 4-7 cm.; sp. pip-shaped, smooth, 8-10 $\times 5-6 \mu$; c. ventricose, $65-75 \times 12-16 \mu$, abundant. Smell strong.

Damp pine woods Britain, France, Germany, Sweden, Finland, Russia, Holland.

The above is the typical form as described by Persoon. Pileus and stem 


\section{Massee.-A Monograph of the genus Inocybe, Karsten. 483}

brown, more or less suffused with purple or lilac; gills at first olive. Flesh tinged lilac at the apex of the stem as in $I$. cincinnala. The last-named Fungus differs from I. obscura in the brownish-violet gills.

Var. rufus, Pat., Tab. Anal., no. 543. About the size of the typical form; differing in the reddish-brown, strongly umbonate pileus, violet gills, and spores much narrowed towards one end; $c$. as in typical form.

In woods. Erance.

Var. major, Fries, Icon. Sel., ii, p. 6, tab. I07, f. 3. This is a larger variety figured and described by Fries.

Forma major, stem 3-4 cm. long, 3-4 mm. thick; pileus more flattened when expanded, umbonate, $5 \mathrm{~cm}$. broad; gills paler.

lacera, Karst., Hattsv., p. 457 ; Sacc., Syll. v, p. $7^{67}$; Ag. (Ino.) lacerus, Fries, Syst. Myc., i, p. 257 ; Cke., Ill., pl. $5^{8} 3$.

P. convex then expanded, often obtusely umbonate, at first smooth then scaly, the scales becoming squarrose, brownish then mouse-colour, at length pale, $2-3 \mathrm{~cm}$.; g. sinuate, adnexed, ventricose, pinkish then mouse-colour; s. slender, short, covered with brown fibrillose flecks, paler than the p., apex not mealy, stuffed, flesh reddish, 3-3.5 cm.; sp. pip-shaped, smooth, 9-II $\times 5-5.5 \mu$; c. ventricose, abundant, $55-70 \times 12-16 \mu$.

On the ground in pine and mixed woods. Britain, France, Germany, Sweden, Russia, Finland, Holland.

Distinguished from $I$. scabra and $I$. mutica by the reddish flesh of the stem.

As understood here, I. lacera is represented in Syd. Myc. March, exs. 2718.

carpta, Sacc., Syll. v, p. 769 ; Quél., Flor. Myc., p. I04; Oudem., Rev. Champ. Pays-bas, 1892, p. 235 ; Mass., Brit. Fung.-Fl., ii, p. 189; Ag. (Ino.) carplus, Fries, Hym. Eur., p. 230; Ag. carptus, Scopoli, Flor. Carniol., ed. 2, vol. ii, p. 449 (1772); non Bresadola, Fung. Trid., i, p. 50, tab. 54.

P. convex then expanding until almost plane, usually at length more or less depressed at the disc, everywhere densely fibrillose, the fibrils sometimes collected into adpressed or more or less erect squamules, which are somewhat concentrically arranged in adult specimens, dusky brown, $1 \cdot 5-2.5 \mathrm{~cm}$.; g. adnate then seceding, or adnexed, broad, ventricose, becoming dark brown; s. hollow, somewhat narrowed downwards, covered with a spreading, fbrillose wooliness, paler than the p., $3-5 \mathrm{~cm}$; sp. pip-shaped, smooth, 8-10 $\times 5-6 \mu$; c. numerous, often slightly curved, ventricose, $60-70 \times 12-15 \mu$.

On the ground in woods, \&c. Britain, France, Germany, Sweden, Italy.

The description given above covers the species admitted.by all European mycologists except Bresadola, whose description and figure quoted above may, as suggested by Saccardo (Syll. v, p. 769), represent a form of I. maritima.

I. umbrina, Bres., which superficially resembles $I$. carpla, differs in having rough spores.

hystrix, Karst., Hattsv., p. 453 ; Sacc., Syll. v, p: 762 ; Agar. hystrix, Fries, Epicr., p. 171 ; Fries, Icon. Sel., ii, tab. 106, f. 1.

P. convex then expanded, obtuse or slightly and obtusely umbonate, orbicular, dull brown to mouse-colour, covered with revolute, squarrose scales which become

\section{1}




\section{Massee.-A Monograph of the genus Inocybe, Karsten.}

fibrillose towards the margin, 4-9 cm.; g. adnate, slightly sinuate, crowded, broadish but not ventricose, greyish then brown; s. solid, firm, equal or often slightly narrowed downwards, or subfusiform, colour of p., with concentric squarrose and revolute floccose scales up to the distinctly marked annular zone, smooth and pallid above,

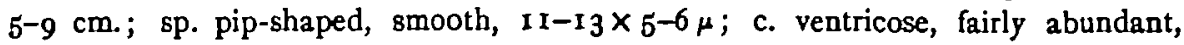
$70-90 \times 12-17 \mu$. Flesh white.

On the ground in woods. Britain, France, Sweden, Germany.

The general appearance of this species suggests a small specimen of. Pholiota squarrosa. Often smaller than the measurements given above. There is no tinge of blue nor green on the stem.

(Specimens from Sweden, determined by Dr. R. Fries, examined.)

8quamosa, Bresad., Atti dell' I. R. Accad. di Sci. Agiati in Rovereto, serr. iii, vol. 3 , fasc. ii, pl. I ( 1902 ).

$P$. convex then expanded, often umbonate, tawny-ochre, densely covered with similarly coloured fibrillose scales, centre somewhat smooth and often areolate, I-I.5 cm.; g. somewhat distant, broad, sinuate, villose from the numerous cystidia, pale tawny; s. subequal, fibrillose, yellowish, stuffed then partly hollow, $1-3 \mathrm{~cm}$; flesh yellowish; ; sp. obovate, smooth, 9-1 I $\times 6-7 \mu$; c. subclavate, $70-90 \times 10-13 \mu$.

On the ground. Portugal.

Resembling $I$. dulcamara and $I$. caisariata, differing in the evidently scaly pileus, broader spores, and prestuce of numcrous cystidia.

incarnata, Bres., Fung. Trid., i, pp. 49 and 102, tab. liii; Sacc., Syll. v, p. 766.

P. campanulate then expanded and broadly umbonate, fibrillose then squamulose, yellowish-red to flesh-colour, margin fimbriate, $6-8 \mathrm{~cm}$; g. crowded, slightly sinuatoadnate, broad, greyish-cinnamon then spotted with red or entirely reddish, edge paler, fimbriate; s. solid, sometimes narrowed downwards, somewhat rooting, slightly fibrillose, reddish, apex white, furfuraceous, $6-8 \mathrm{~cm}$. long, ro-1 $5 \mathrm{~mm}$. thick, flesh red from the first; sp. pip-shaped, smooth, $9-10 \times 6 \mu$; c. basidia ventricose or clavate, $55-65 \times 12-16 \mu$. Flesh of p. white, becoming red when cut. Smell very strong, like ripe pears.

In pine and other woods. Britain, France, Austria.

Differs from $I$. pyriodora in being more robust in build, deeper red colour, and stronger odour. As defined above, this Fungus appears to be a distinct species, yet I am not certain that we are dealing with more than one species, of which $I$.pyriodora and $I$. incarnata represent the two poles. Transitional forms are not uncommon in this country which are just off one type and tending towards the other.

During the Y. N. U. Fungus Foray at Helmsley, specimens of the $I$. incarnata type were found which certainly were exaggerations of this type; pileus broken up into coarse subsquarrose scales, colour deep red everywhere, smell exceedingly strong and resembling that of hyacinth flowers.

Morphologically there is no difference between $I$. pyriodora and $I$. incarnata.

griseoscabrosa, Mass.; Ag. (Heb.) griseoscabrosws, Peck, 26 Rep. State Mus., p. 57 (1873); Sacc., Syll. v, p. 796.

P. hemispherical, dry, rough with adpressed fibres and scales, grey, margin whitish when young, I-2 cm.; g. crowded, broad, whitish when young then ochre- 


\section{Massee.-A Monograph of the genus Inocybe, Karsten. 485}

brown; s. firm, equal or slightly tapering downwards, solid, fibrillose or slightly scaly, nearly colour of p., 3-5 cm.; sp. smooth, elliptical, $9 \times 5 \mu$; c. rare, subfusiform, 45-55 $\times 12-16 \mu$.

Gregarious on ground in woods. United States (Bethlehem).

(Peck's type examined.)

mutica, Karst., Hattsv., p. 459 ; Sacc., Syll. v, p. 769 ; Ag. (Ino.) muticus, Fries, Mon, ii, p. 346 ; Icon. Sel., tab. I०9, f. r ; Cke., Ill., pl. $3^{82 .}$.

P. convex then plane or slightly depressed, very obtuse, whitish or tinged ștrawcolour with darker adpressed squamules, $3 \sim 5 \mathrm{~cm}$.; g. broadly adnate, crowded, tinged brown; s. short, $3-5 \mathrm{~cm}$., rather stout, bollow, fibrillose, slightly narrowed downwards, straw-colour; sp. pip-shaped, smooth, $8-9 \times 5 \mu$; c. abundant, ventricose, $50-60 \times 14-16$.

Side of paths in woods, \&c. Britain, Sweden, France, Germany.

Fragments of the fibrillose veil sometimes attached to edge of pileus in young specimens. Quélet (Flor. Myc., p. I06) considers that Ag. tomentosus, Jungh., Linn. I830, t. 6,f. 7 , is an Inocybe, and has placed $I$. mutica as a variety, and $I$. eutheles as a synonym under this species. It is more than doubtful whether any other mycologist would have seen an Inosybe in Junghuhn's figure, which is furnished with a distinct ring on the stem.

(Specimen from Fries examined.)

eutheloides, Peck, 32 Rep. State Mus., p. 29 ; Sacc., Syll. ix, p. 99.

P. conical or campanulate then expanded and umbonate, silky-fibrillose, somewhat cracked, greyish fawn-colour to chestnut-brown, disc sometimes squamulose, I 2-I 4 mm. ; g. rather crowded, ventricose, broadish, narrowed behind and adnexed, whitish then rusty-brown, edge white and denticulate; s. equal, subflexuous, fibrillose, $2-2.5 \mathrm{~cm}$.; sp. elliptical, smooth, 8-10 $\times 5^{-6} \mu$; c. fairly abundant, ventricose, $45-55 \times 12-16 \mu$

On the ground in woods. United States (Brewertown).

Closely allied to $I$. eutheles, differing mainly in the gills being narrowed behind and adnexed. Also allied to $I$. pallidipes.

(Type from Peck examined.)

nigrodisca, Peck, 4I Rep. State Mus., p. 67 (1888); Sacc., Syll. ix, p. 99.

$P$. convex then almost plane, or the centre depressed, umbonate, very minutely fibrillose, blackish-brown, margin greyish, $1.5 \mathrm{~cm}$; g. free or subadnexed, rounded behind, crowded, greyish then rusty-brown, sometimes tinged yellow; s. slender, firm, solid, flexuous, minutely pruinosely downy, reddish-brown, $2 \cdot 5-3.5 \mathrm{~cm}$.; $\mathrm{sp}$. subelongate, smooth, $5.5-6.5 \times 4.5-5 \mu$; c. fairly abundant, stout, slightly ventricose, 40-50 $\times 12-15 \mu$

Under Osmunda cinnamomea, United States (Kasaag, Osw.).

Allied to $I$. paludella.

(Peck's type examined.)

Raveneli, Massee (sp. nov.).

P. campanulate then expanded and rather acutely umbonate, brown, silkyfloccose, $\mathbf{I} \cdot 5^{-2.5} \mathrm{~cm}$; g. adnate, broad, pale brown; $\mathrm{s.} 3-4.5 \mathrm{~cm}$., slender, smooth, hollow, paler or same colour as pileus; sp. elliptic-oblong, obliquely apiculate, L12 


\section{Massee.-A Monograph of the genus Inocybe, Karsten.}

smooth, averaging $15 \times 5 \mu$, some reaching up to $18 \mu$ long; c. fusoid or subventricose, thin-walled, rare and apt to be overlooked, $45-55 \times 12-15 \mu$

I have ventured on describing as new this Fungus, which appears to be not uncommon in the United States. The ticket accompanying Ravenel's specimen, which may be regarded as the type, bears a full description of the Fungus, accompanied by two sketches in ink. The principal features of the Fungus are the long narrow spores and acute umbo.

On the ground in damp places. United States.

It is represented in the Kew Herbarium as follows: 'Rav., 2416 , April $14,1878$. On the ground in damp places, near Darien, Georgia' (as I. maritima). 'Maine, U.S.A.' (as I. geophylla). ' 'C. Wright, Connecticut, 55०5' (as I. dulcamara). 'Car. Inf. no. 282I' (as $I$. Bougardii).

brunnea, Quél., Soc. Sci. nat. Rouen, r879, tab. 2, f. 7 ; Flor. Myc., p. ror ; Sacc., Syll. v, p. 776.

P. campanulate, umbonate, fibrillosely silky, then cracked, chestnut, $0.5 \mathrm{~cm}$.; $\mathrm{g}$. emarginate, uncinate, creamy then bistre, edge white and crenulate; s. solid, thickened at the base, clear brown, apex white and pruinose, $2-3 \mathrm{~cm}$.; sp. pip-shaped, smooth, 9-12 $\times 4-5 \mu$; c. ventricose, scattered, $60-65 \times$ I 4-I $7 \mu$.

Grassy places in woods. France.

(Specimen from Quelet examined; Roum., Fung. Sel., exs. 599 I, is also the correct species.)

haemacta, Sacc., Syll. v, p. 763 ; Ag. (Ino.) haemactus, B. and Cke., Grev., xi, p. 70 ; Cke., Ill., pl. 390.

P. campanulate then expanded, obtuse, umber becoming paler towards the margin, clad with long, darker fibrils, disc darkest and rather scaly, $2-3 \mathrm{~cm}$. ; g. slightly rounded behind, adnate, dingy tan; s. whitish above, tinged verdigris-green at the base, solid, smooth, 4-5 cm., rather stout ; sp. pip-shaped, smooth, 9-I I $\times 5 \mu$; c. ventricose, 50-70 $\times$ 17-20, fairly numerous. Flesh everywhere duanging to red when cut.

Among short grass. England.

The green colour of the stem extends through the flesh. Differs from $I$. calamistrata in the absence of squarrose scales.

(Type specimen examined.)

rhodiola, Bres., Fung. Trid., p. 8o, tab. 87 (forma gracilis); Ino. frumentacea, Bres., Fung. Trid., p. 88, tab. 200 (forma typica); Ino. jurana, Pat., Tab. Anal., no. 55 I (fide Bresadola).

P. fleshy, campanulate then expanded and umbonate, fibrillosely cracked, centre even, rufous-chestnut or fuscous flesh-colour, $4-8 \mathrm{~cm}$; g. crowded, sinuato-uncinate, almost free, edge fimbriate, white then yellowish umber, often spotted with brownish umber ; s. fibrilloso-squamulose, becoming glabrous, vinous, apex pallid, subfloccose, 5-8 cm. long, I-I.5 cm. thick, stuffed; flesh white, vinous at base of stem; spores subreniform, smooth, 10-12 $26-8 \mu$, some 14-15 $58 \mu$; large cells on edge of gills clavate or subfusoid, $50-60 \times 12-14 \mu$. Smell resembling meal.

On the ground in coniferous woods. Austria, France.

Bresadola considers the present species to be the true $\mathrm{Ag}$. frumentaceus of Bulliard, and gives the following synonymy :- 


\section{Massee.-A Monograph of the genus Inocybe, Karsten. 487}

'Inocybe frumentacea (Bull.), Bres., Fung. Trid., p. 88, tab. 200; Agaricus frumentaceus, Bull., Champ. France, tab. 57I, fig. I ; Ino. jurana, Pat., Tab. Anal., no. 551; Ino. rhodiola, Bres., Fung. Trid., p. 80, tab. 87 (forma gracilis).'

Bresadola is by no means the first mycologist who has essayed to define the exact species Bulliard's figure represents, and judging by the diversity of opinion expressed, the task appears to be bopeless, and one would imagine, not profitable.

Fries (Hym. Eur., 52) considers the Fungus in question to be a Tricholoma; Berkeley (Outl. p. 144) places it in Entoloma; Quelet (Flor. Myc. 262) regards it as synonymous with Hygrophorus russula, Schaeffer.

No type specimen of Bulliard's Fungus has been discovered, and Bresadola, like other people, has only the old figure to go by, and as Bulliard's figures were handcoloured, and variable within fairly wide limits in different copies, I have decided not to admit Bulliard's figure, already claimed.by so many mycologists, into the genus Inocybe, but have restored Bresadola's first name given to this Fungus, which is obviously an Inocybe.

fuscodisca, Mass.; Ag. (Heb.) fuscodiscus, Peck, 27 Rep. State Mus., p. 95, pl. I, figs. 3-6 (1874); Sacc., Syll. v, p. 796.

P. at first subviscid, conical, covered with blackish-brown fibrils, then campanulate or expanded and umbonate, whitish, the disc remaining blackish-brown, $1 \cdot 5-2.5 \mathrm{~cm}$.; g. crowded, white then brownish, edge minutely fimbriate; s. equal and solid, whitish and pruinose at the apex, remainder brownish, fibrillose, $3-7 \mathrm{~cm}$.; sp. pip-shaped, smooth, 8-10 $\times 5-5.5 \mu$; c. ventricose, fairly numerous, $45-55 \times 12-16 \mu$. The odour like chestnut blossom.

In an old pasture under trees. United States (Forestburgh).

The somewhat viscid pellicle is separable.

(Peck's type examined.)

comatella, Peck, $3^{8}$ Rep. State Mus., p. 87 , tab. ii, f. $5^{-8}$; Sacc., Syll. v, p. 791 .

P. convex or expanded, covered with whitish or greyish hairs, margin fimbriate, 4-8.5 mm.; g. adnate, rather distant, pale cinnamon; s. equal, solid, flexuous, pallidor rufous-brown, then darker, slightly mealy or pruinosely-fibrillose, with white .mycelium at the base, $2-2.5 \mathrm{~cm}$; sp. pip-shaped, smooth, $8 \times 4-4.5 \mu$; c. strongly ventricose, $45-55 \times 12-20 \mu$.

On trunks and branches among dead leaves. . United States.

Intermediate between $I$. tricholoma and $I$. strigiceps (Peck).

(Peck's type examined.)

flocculosa, Sacc., Syll..v, p. 768; Ag. (Iro.) flocculosus, Berk., Engl. Fl., v, p. $97(1836)$.

P. convex or subcampanulate, umbonate, silky-squamulose, brownish-fawn colour, $2.5 \mathrm{~cm}$. ; g. rounded behind and adnate but not broadly so, pale fawn then dull rusty, edge white; s. fibrillose, apes squamulose, brownish beneath the fibrils, $3 \mathrm{~cm}$; ; sp. elliptical, smooth, 8-10 $\times 5^{-6} \mu$; c. abundant, ventricose, $50-60 \times 12-15 \mu$. Smell mealy but unpleasant.

On naked soil and among grass. Britain. 


\section{Massee.-A Monograph of the genus Inocybe, Karsten.}

Amongst grass the pileus is smoother, more tawny, rimoso-sericeus; gills not arcuate behind but broadly adnate (Berk.).

Allied to I. Lanuginosa and I. lacera; the former differs in the obtuse pileus with squarrose squamules at the disc, and the latter in the naked apex of the stem.

(Type specimen examined.)

conformata, Karst., Krit. Ofvers. Finl. Basid., p. 465 (1889); Sacc., Syll. ix, p. 98 ; I. pusio, Karst., Krit. Öfvers. Finl. Basid., p. $4_{5}$ (1889); Sacc., Syll. ix, p. 98.

P. convex then expanded, umbonate, fibrilloso-rimose and sometimes minutely adpressed floccoso-squamulose, pale fuscous or tinged rusty, I-3 cm.; g. adnexed, somewhat crowded, ventricose, pallid then brownish; 's. solid, equal, often flexuous, minutely fibrillose, apex at first tinged violet, $3-5 \mathrm{~cm}$; sp. pip-shaped, smooth, 8-10 $\times 4^{-6} \dot{\mu}$; c. ventricose, $70-80 \times 10-15 \mu$, sometimes much thicker.

Mossy ground near paths. Finland.

The two forms enumerated above agree in all essential features, and cannot be separated as species; in fact Karsten states that $I$. pusio is externally exactly similar to $I$. conformata, but is distinguished by the thicker cystidia. This feature alone, however, cannot constitute a species.

(Types of $I$. conformata and $I$. pusio, from Karsten, examined).

+† Gills tinged olive.

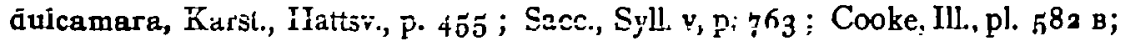
Pat, Tab. Anal:, no. 610; Ag. dulcamarus, A. and S., Consp. Fung., p. I 7 I (1805).

- P. campanulate then expanded and umbonate, brownish-olive, floccosely scaly, margin more or less fimbriate and silky, $2-5 \mathrm{~cm}$.; g. narrowed behind, arcuately adnesed, rounded in front, crowded, pallid, then distinctly olive; s. imperfectly hollow, fibrillose from the veil, adpressedly scaly, paler than p., apex mealy, 4-6 cm.; sp. pip-shaped, smooth, I I-1 $3 \times 5-6 \mu$; c. fairly abundant, ventricose, $55-65 \times 15-18 \mu$. Flesh tinged yellow.

On the ground in pine woods, \&c., gregarious. Britain, France, Germany, Sweden.

The above diagnosis agrees with the views of Patouillard and Quelet as to the plant described by Fries (Hym. Eur., p. 228) as Ag. (Ino.) dulcamarus, and referred by him to the Fungus described by Albertini and Schwein.z in Consp. Fung., p. I 7 I. Why Fries connected the Fungus found by him with the plant mentioned by Albertini and Schweiniz is not quite clear, judging from the description furnished by these authors, which is as follows :-

'489. A. G. dulcamarus. Exempla juniora Corlinariam et hanc esse, velo fugaci instructam, demonstrant. Stipes subcavus, subfibrillosus. S Sapor Glycyrrhisae dilutus. Varietatem hujus speciei habemus alteram autumnalem squamulis pilei appressis, lamellis dilutius olivascentibus; alteram aestivalem squamis distinctioribus subsquarrosis, lamellis saturatius olivaceis.'

relicina, Karst., Hattsv., p. 453 ; Sacc., Syll. v, p. $76_{4}$; Ag. (Ino.) relicinus, Fries, Syst. Myc., i, p. $25^{6 .}$

P. conical then expanded, obtuse, covered everywhere with squarrose scales formed of fasciculate fibrils, dingy brown, $1 \cdot 5-2 \cdot 5 \mathrm{~cm}$. ; g. slightly adnexed, crowded, 


\section{Massee.-A Monograph of the genus Inocybe, Karsten. 489}

yellow then olive; s. solid, soft, equal, fibrillosely scaly (not squarrose), apex paler, 4-5 cm., colour of p.; sp. pip-shaped, smooth, 10-12 $27 \mu$; c. ventricose, scattered, $70-85 \times \mathrm{I}_{4}-\mathrm{I} 6 \mu$

Damp pine woods amongst Sphagnum, \&c. Britain, Ireland, France, Sweden.

Most nearly allied to $I$. dulcamara, which differs in the umbonate pileus with an olive tinge.

(Specimen in Herb. Kew. determined by Klotzsch accepted as typical. This agrees with Quélet's conception of the species.)

Bongardi, Karst., Hattsv., p. 458 ; Ag. Bongardi, Weinm., Hymeno- et GasteroMycetes Imp. Rossica Obs., p. I90 (1836).

$P$. campanulate then expanded, obtusely umbonate, whitish with a rufescent or yellowish tinge, covered with darker fibrillose squamules, $3-7 \mathrm{~cm}$; g. arcuato-adnate, crowded, ventricose, broad, whitish then olive-cinnamon, finally dusky cinnamon, edge eroded ; s. solid, equal, stuffed, straight, yery tough, almost smooth, colour of p., apex with white meal, $5^{-8} \mathrm{~cm}$; sp. pip-shaped, smooth, 8-10 $5^{-6} \mu$; c. ventricose, scattered, $50-65 \times$ I $3-16 \mu$. Flesh reddish when cut. Smell pleasant, like ripe pears.

In woods. Britain, Russia.

The above is the diagnosis given by Weinmann, so far as macroscopic structure is concerned. I have collected specimens in England agreeing admirably with the above, which differs very materially from the diagnosis given by Fries (Hym. Eur., p. 229), and also from his figures (Icon. Sel., tab. 107).

If Fries' Fungus is in reality the same species as Weinmann's, it is a marked variety, differing more especially in the following points. Pileus darker in colour and more distinctly squarrosely scaly; flexuous stem; gills not arcuate.

+H Gills tinged violet.

cincinnata, Karst., Hatisv., p. $45^{6}$ (1879); Bres., Fung. Trid., i, p. 47, pl. 5r, f. 2 (1881); Sacc., Syll. v, p. 764; Ag. cincinnatus, Fries, Syst. Myc., i, p. 256

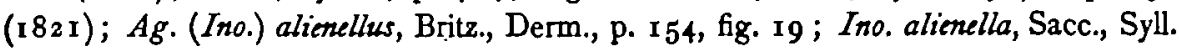
v, p. 764 .

P. convex then expanded, obtuse or obsoletely umbonate, dusky brown, disc with more or less squarrose floccose squamules, margin fibrillose, $\mathrm{I} \cdot 5-3 \mathrm{~cm}$.; g.adnexed, seceding, crowded, ventricose, brownish-violet; s. solid, rigid, slender, fibrillosely 6quamulose, apex tinged violet at first, then discoloured, $3^{-4} \mathrm{~cm}$.; sp. pip-shaped, smooth, 8-12 $\times 5^{-6} \mu$; c. subcylindrical or slightly ventricose, fairly abundant, 60$80 \times 14-18 \mu$ Flesh white except apex of stem, which is lilac at first.

On the ground in woods. Britain, France, Germany, Sweden; Austria, Bavaria, Holland.

Superficially more or less resembles several species. 1 . obscura differs in the non-squamulose stem, and gills olive at first. I. fulvella has nodulose spores.

\section{Cystidia absent.}

\section{* Stem whitish or pallid.}

+ Gills brownish, ochraceous or cinnamon.

perlata, Sacc., Syll. v, p. 774 ; Ag. (Ino.) perlalus, Cke., Grev., xv, p. 40 ; Cke., Ill., pl. 960. 


\section{Massee.-A Monograph of the genus Inocybe, Karsten.}

P. convex then expanded and broadly umbonate, fuscous, longitudinally streaked with darker fibrils, disc darker, edge paler, incurved, 6-10 $\mathrm{cm}$; g. rounded behind, adnexed, broad, pallid then pale umber; s. straight or curved, sometimes twisted, fibrously striate, pallid and mealy above, darker below, 6-10 $\mathrm{cm}$. long, $1-1 \cdot 5 \mathrm{~cm}$. thick; flesh dingy white; sp. elliptical, smooth, $9-12 \times 6-7 \mu$; c. absent.

Under hornbeam. Britain.

Resembling $I$. fibrosa in size, differing in the smooth spores and darker pileus.

(Type specimen examined.)

perbrevis, Karst, Hattsv., p. 462; Sacc., Syll. v, p. 777; $\mathrm{Ag}$. (Ino.) perbreois, Cke., Ill., pl. 519; Ag. perbreois, Weinm., Hymeno- et Gastero-Mycetes Imp. Ross. Obs., p. $185(1836)$.

P. convex then expanding until almost plane, obtusely umbonate, often depressed round the umbo, fibrillosely. silky or minutely squamulose, rufous-brown becoming tinged yellowish, margin fibrillose and often splitting, $1 \cdot 5-3 \mathrm{~cm}$.; g. slightly adnexed with a slight decurrent tooth, ventricose, rather distant, pale then tan-colour; 8. stuffed, often slightly narrowed downwards, pallid and white-fibrillose, $2-2.5 \mathrm{~cm}$.; sp. elliptic-oblong, apiculate, smooth, 8-9 $\times 4.5-5 \mu$; c. absent.

Gregarious; on the ground in woods, \&c. Britain, Russia, Germany, Sweden; United States (N. Jersey, E. \& E., N. Amer. Fung, ser. ii, r 903).

A frm, compact little Fung1s, recognized by the rufous-brown colour, short stem, and absence of cystidia.

fuegiana, Sacc., Syll. ix, p. ror ; Ag. (Ino.) fuegianus, Speg., Fung. Fueg. in Bol. Acad. Nac. Cord6ba, xi, p. r 44, no. 25 (r887).

P. hemispherical then plano-expanded, disc almost glabrous, not at all or slightly depressed, the remainder densely papillosely villose, chestnut or smoky-brown, edge entire wavy or undulate, $6 \mathrm{~cm}$. ; g. sinuato-adnate, $\mathbf{c m}$. broad, rather distant, attenuated in front, greyish,brown, edge quite entire; s. short and thick, $5 \mathrm{~cm}$. long, I $\mathrm{cm}$. thick above, $2 \mathrm{~cm}$. thick below, straight fibrillose, white then smoky-brown; sp. 'elliptical, smooth, ends obtuse, ro-1 $3 \times 5^{-6} \mu$.

In beech woods. . Tierra del Fuego (Ushuvaia, Beagle Channel).

Solitary. Allied to $I$. caesariata.

Victoriae, Sacc., Syll. ix, p. Ior ; Ag. (Ino.) Victoriae, Cke. and Massee, Grev., xvi, p. $7^{2}$ (I 888).

P. convex then expanded and umbonate, whitish, viscid, glabrous, silky and shining, disc darker, $2-3 \mathrm{~cm}$; g. sinuate and adnexed then almost free, pale then umber ; s. almost equal, white, glabrous, stuffed, $3-5 \mathrm{~cm}$; sp. elliptical, smooth, i II $2 \times 7-8 \mu$; c. absent.

On grassy ground. Victoria (F. Reader, no. 26, with figs. and description).

Very near to Hebeloma, but the pileus is distinctly silky-fibrillose.

(Type examined.)

holophlebia, Sacc, Syll. xi, p. $5^{2}$; Agaricus (Ino.) holophlebius, Berk., in Herb. Grev., xix, p. I04.

P. campanulate then expanded and umbonate, floccosely fibrillose, disc squamulose, fawn-colour or dull, pale yellow, $3^{-6} \mathrm{~cm}$; g. adnate, broad, tan then brownish; 
s. cylindrical, slender, equal, whitish, 5-6 cm.; sp. broadly elliptical, smooth, I 2-1 4 $\times 8 \mu$; c. absent.

$\therefore$ On the ground. India (Masulipatam). :

A fine, large species, superficially resembling $I$. pyriodor $\dot{a}$. The specimens, collected by Berkeley's son, are accompanied by coloured sketches.

(Type specimen examined.)

subdecurrens, Ellis and Everh., Journ. Myc., v, p. 27 (1889); Sacc.; Syll. ix, p. 97 ; I. tomentosa, Ellis and Everh., Journ. Myc, v, pp. 27-28 (1889).

P. convex then plane, disc depressed and with or without a small umbo, densely adpressed pilose or tomentose, pale drab becoming yellowish, $2-5 \mathrm{~cm}$.; $\mathrm{g}$. adnatodecurrent; dingy cinnamon, edge serrulate ; s. fibro-squamulose above, white-tomentose, hollow throughout or only upwards, $2-4 \mathrm{~cm}$; sp. elliptical, ends obtuise, often very slightly curved, smooth, 8-10 $\times 5-6 \mu$; c. absent. N.Y.).

On the ground under branches of Norway spruce. United States (Newfield,

After a very careful examination of authentic specimens. from Ellis and Everhart's exs., I feel constrained to consider that but one species is present. 'Both were found under the same tree, and both 'manifest the same salient features, among which are the depressed disc, a rare feature in Inocybe; serrulate gills, agreement in form and size of spores, and in. the absence of cystidia. In the dried condition the gills show a decided olive tinge.

Ellis however does not bold the above view, and, in a paragraph following the diagnoses of these forms, says :-

:. 'I. subdecurrens is-larger, with a hollow stem, and has the gills more crowded, nor is the margin incurved and tomentose, and it is also rather a darker shade and has the margin of the gills more strongly serrate.'

In $I$. tomeritosa the margin remains incurved till the plant is nearly full grown.

In 1 . subdecurrens the margin is never incurved, even when young, nor is there any annular mark on the stem, though the fibrous veil is at first distinct.

(Specimens from Ellis and Everh., N. Amer. Fung., ser. ii, nos. I 906 and 2 ror examined.)

vatricosa, Karst., Hattsv., p. 465 ; Sacc., Syll. v, p. $790^{\circ}$; Ag. (Ino.) vatricosus, Fries, Syst. Myc., i, p. 259 ; Icon. Sel., ii, p. 9, tab. I ro, f. 3.

$\therefore$ - P. convex then plane, obtuse or umbonate, smooth, glabrous, becoming silky towàrds the margin, viscid when moist, shining when dry, white, $1 \cdot 5^{-2} \cdot 5 \mathrm{~cm}$. sometimes broader; g. emarginate, slightly adnexed, almost free, crowded, whitish then brown; s. fistulose, white, entirely covered with white down, not fibrillose, ascending or flexuous, about equal, $2-5 \mathrm{~cm}$. ; sp. elliptical, smooth, $5-6 \times 3-3.5 \mu$; c. absent.

On the ground or on fallen chips, in damp woods. Britain, Sweden, Finland, Russia.

Very variable in size, usually small; superficially resembling $I$. geophylla, but generally smaller, and differing in absence of cystidia. Quite as much a Hebeloma as an Irocybe.

+t Gills: tinged olive.

fbrillosa,.Peck, 4 I Rep. State Mus., p. 65 (1888); Sacc, Syll ix, p. 98. 


\section{Massee.-A Monograph of the genus Inocybe, Karsten.}

Berkeley considered it as a Lepiota, whereas Fries placed it in Psalliota, and Cooke in Irocybe. The spores appear to be yellowish-brown and, as it were, only stained by the red juice which permeates every part of the Fungus. 1. echinata is probably an introduced. species in. Europe, never occurring in woods, \&c., but only in conservatories or botanical gardens.. The occurrence of specimens from Cayenne and S. Carolina suggest that it may be indigenous to the New World.

( $T$ ypes of Berkeley and Klotzsch examined.)

violacea, Massee, Kew Bull., 1899, p. 169 ; Sacc., Syll. xvi, p. 91.

P. campanulate then expanded and broadly-umbonate; squamulose, edge fimbriate, violet, paler towards the margin, $\mathrm{I}-\mathrm{I} \cdot 5 \mathrm{~cm}$.; g. sinuato-adnate, crowded, narrow, white then tinged rosy flesh-colour, edge fimbriate; s. solid, equal, subfibrillose, rosy flesh-colour, àpex .white-scurfy, 2-3 $\mathrm{cm}$; sp. cylindric-ovate, apiculate, smooth, $6 \times 3-3: 5 \mu$; c. absent.

On a lawn. Perak.

Allied to $I$. echinata.

rhombospora, Massee (sp. nov.).

P. campanulate, rather acutely umbonate, fibrillose, brown, edge paler; disc squamulose, $2-3 \mathrm{~cm}$; $\mathrm{g}$. adnexed, rather crowded, yellowish brown; $\mathrm{s}$. fibrillose, brown, with white silky fibresı up to the imperfect annular zone, $3-4 \mathrm{~cm}$; sp. rhomboidal, sometimes with a. marked apical point, $6 \times 5 \mu$, compressed laterally; c. absent.

$\because \quad$ On rotten wood. India (Nilghiris).

The specimen was collected by Berkeley's son, and placed under ' undẹtermined species.'. It is now in the Kew' Herbarium.'

Readily distinguished by the peculiar spores. 'The basidia are also exceptional in structure, measuring $20 \times 9-i \circ \mu$; the sterigmata are reduced to minute papillae.

There is an American species included in 'Rav., Fung. Amer., exs. 20r, ad terram arenosam, Darien, Florida, 20r,' called Ag. Ino. maritimus. The spores have a more or less rhomboidal form in outline, smooth, and $4 \cdot 5-5 \times 4 \mu ; c$. absent. This species is certainly not I. maritima, and does not.accord with any described species. As no diagnosis can be drawn up from the imperfectly preserved specimens, which are not accompanied by notes or sketches, it remains for American mycologists to look to this interesting form.

If the occurrence of $I$. maritima in the United States turns on this species, the name must be deleted from the list.

H Gills tinged olive.

erythroza, .De Seynes, Rech. Champ. Congo Fr., i; p. 2, tab. I, f. I-5. (1897); Sacc., Syll. xiv, p. 133 .

P. plane or subdepressed, subumbonate, margin at length irregularly reflexed, rusty, ornamented with pyramidal-reddish spines, 1.5-2.cm.; 'Alesh yellowish; tough'; g. ventricose, free or slightly adnexed; distant, deep olive, edge paler; s. smooth, yellowish, base paler, becoming hollow, $1 \cdot 5 \mathrm{~cm}$; sp. elliptical, smooth, $7 \times 3^{-4 \mu}$; c. absent.

On the ground. French Congo State. 


\section{Massee.-A Monograph of the genus Inocybe, Karsten. 495}

p. roo.

murino-lilacina, Ellis and Everh., Journ. Myc., v, p. 25 (1889); Sacc., Syll. ix,

P. silky-fibrillose, at length becoming squamulose around the margin, with a broad prominent disc, mouse-colour with a tinge of lilac when fresh and young, $2-4 \mathrm{~cm}$.; g. adnate, rather broad, rusty with just a tinge of olive; $s$. fistulose and soon hollow, fibrillose, about colour of p., 2-4 cm.; sp. pip-shaped, smooth, $8-9 \times 4.5-5 \mu$; c. absent.

On the ground in dry, bushy places. United States.

The broad, prominent disc of the pileus either has a small umbo in the centre or a slight depression, and is generally surrounded (about half-way to the margin) with a distinct ridge or zone. The margin also projects slightly, and is a little lighter coloured and, under the lens, subfimbriate (E. and E.).

(Specimen in Ellis and Everb., N. Amer. Fung., ser. ii, 1905, examined.)

subtomentosa, Peck, 48 Rep. State Mus., p. Io9 (1894); Sacc., Syll. xiv, p. I34.

P. conver or plane, minutely hairy-tomentose, brownish-tawny, up to $2.5 \mathrm{~cm}$.; g. adnate, slightly emarginate, crowded, whitish then tinged olive, finally tawny brown, edge whitish, crenulate; s. short, solid, slightly silky-fibrillose, coloured like p., or a little paler, $2.5 \mathrm{~cm}$. ; sp. elliptical, smooth, sometimes inclined to be curved, 8-10 $\times 5-6 \mu$; c. absent.

Gregarious or subcaespitose. Gravelly soil among fallen leaves. United States (Rouse's Point).

Very closely allied to $I$. tomentosa; however Peck considers the two as distinct, and distinguished as follows:-

Differs from $I$. tomenlosa by its darker colour, larger spores, and the entire absence of an umbo. Its prominent features are its small size, minutely tomentose pileus, and nearly uniform brownish-tawny colour when mature. I. fibrillosa by its solid merely fibrillose stem, and by the absence of scales on the disc of the pileus (Peck).

(Type from Peck examined.)

fastigiata, Karst., Hattsv., p. 461 (1879); Bres., Fung. Trid., i, p. 52, tab. 57; Ag. fastigiatus, Schaeff., Fung. Ic., tab. 26 (1800); Ag. (Ino.) Curreyi, Berk., Outl., p. 155 ; I. Curreyi, Sacc., Syll. v, p. 775 ; Ag. (Ino.) setvatus, Britz., Hym. Sudbay., 1885 , p. 52, fig. 57 ; 1. servata, Sacc., Syll. xi, p. 53 .

P. conico-campanulate, gibbous or obtusely umbonate, or sometimes acutely umbonate when small in size, longitudinally fibrillose and slightly cracked, the disc alone sometimes slightly squamulose, pale yellowish brown, edge sometimes slightly wavy or lobed, 3-6 cm.; g. free, ventricose, rather crowded, narrowish, yellowish then dusky olive; s. subequal, solid, minutely fibrillose, paler than p., 5-10 cm.; sp. elliptical, sometimes slightly curved, smooth, 8-1 I $\times 6-7 \mu$; c. absent.

In woods, \&c. Britain, France, Germany, Bavaria, Austria, Sweden, Finland, Holland.

As defined above, this Fungus is acknowledged as Ag. fastigiatus, Schaef., by Quélet, Karsten, Patouillard, Gillet, Bresadola, and Oudemans. Its prominent characters are the yellowish-brown pileus, olive gills, smooth elliptical spores, and 


\section{Massee.-A Monograph of the genus Inocybe, Karsten.}

absence of cystidia. The pileus is commonly obtusely umbonate, but in the form figured by Bresadola the umbo is acute; in other respects, however, his plant is typical.

There are, however, apparent contradictions to the above view. Fries (Hym. Eur., 232) gives a good description of Schaeffer's Fungus as defined above, and quotes Schaeffer's figure, but at the end of his remarks on the species adds 'sporae scabrae.'

Fries did not personally investigate the microscopic characters of spores, hence this statement must have been obtained from some outside source, and its value questionable.

In Cooke's Illust., pl. $3^{8} 3$, the spores are shown to be rough; this is a mistake, however, as the specimens from which Cooke's figure was drawn, now in Herb. Kew., have smooth spores!

In Saccardo's Sylloge, v, p. 779, the Friesian description of I. fastigiata is copied, with an added description of rough spores and cystidia, obtained from some other source, hence valueless.

In British Fungus-Flora, ii, p. 192, not having an authentic specimen, I copied Saccardo's account of spores and cystidia, hence this cannot be urged as an argument.

(Berkeley's type of 1 . Curreyi examined.)

\section{Spores smooth; no knowledge of cystidia.}

- Pileus dark coloured.

mutata, Mass., Ag. (Heb.) mulatus, Peck, 24 Rep. State Mus., p. 69; Sacc., Syll. v, p. 799 .

P. convex or broadly conical, gibbous, rough with squarrose, fasciculate, floccose scales, which at length disappear except at the disc, dark brown, $1.5-2.5 \mathrm{~cm}$; g. broad, crowded, ventricose and very deeply emarginate, dark rusty-brown, edge whitish; s. slender, equal, solid, floccosely scaly, often curved at the base, colour of p., $5-7.5 \mathrm{~cm}$; sp. elliptical, smooth, $10 \mu$.

Damp ground in woods. United States (Catskill Mts.).

The changed appearance produced by the disappearance of the scales suggests the specific name (Peck).

cucullata, C. Mart., Bull. Soc. Gen., vii, 1892-1894, p. I 79 ; Sacc., Syll. xiv, p. $13^{2}$.

P. variable in form, campanulate, campanulate-convex or sometimes rather irregular, tawny, scaly, those of the disc darkest, $1.5-3 \mathrm{~cm}$; g. broad, adnexed then free, rather crowded, ochre then rusty-brown, edge white, serrulate; s. equal or narrowed below, hollow, glabrous, usually curved or flexuous, $2-4 \mathrm{~cm}$., paler than pileus; sp. pip-shaped, smooth. Smell like camphor.

Among grass. Switzerland.

tuberosa, Clements, Univ. Nebraska Bot. Surv., I893, ii, p. 40 ; Sacc., Syll. xi, p. $\mathbf{5}^{2}$.

P. expanded, scaly, deep brown, $3 \mathrm{~cm}$; g. distant, adnexed, deep brown; 8. tuberous, equal above, gilvous, $4 \mathrm{~cm}$.; sp. pip-shaped, smooth, $6 \times 4 \mu$.

United States (Sioux Co.). 
violascens, Quél, Jura et Vosg., xiv Suppl., p. 4, tab. xii, f. 6; Flor. Myc., p. 103 ; Sacc., Syll. v, p. 766.

P. conico-campanulate, fibrillose, silky, clear buff to brown, velvety and lilac at the disc, $2.5 \mathrm{~cm}$; g. adnate, narrow, lilac then bistre; s. hollow, silky, striate and lilac under a white, silky cortina, $3-5 \mathrm{~cm}$.; sp. pip-shaped, smooth, 12-15 $56 \mu$.

Among grass, appearing in spring. France.

Allied to $I$. corydalina, resembles the violet form of $I$. geophylla.

tenebrosa, Quél., Assoc. Franc., 1885, t. 8, f. 8 ; Sacc., Syll. v, p. 775.

P. campanulate, minutely velvety, yellowish-brown, $2-3 \mathrm{~cm}$; g. adnate, narrow, ochraceous then brown; s. slender, fibrillose, striate, dusky brown or olive, apex whitish, 3-4 cm.; sp. elliptical, apiculate, sometimes slightly curved, smooth, $7-8 \times 4 \mu$.

In woods, spring. France.

Merletii, Quél., Assoc. Franc., 1884, t. 8, f. 7 ; Sacc., Syll. v, p. 769.

P. convex, greyish, speckled with brownish fibrillose flecks, $3-5 \mathrm{~cm}$.; g. sinuate, pale then brownish; s. whitish, streaked with yellow-brown fbrils underneath a white cobweb-like veil, 4-7 cm: sp. elongato-elliptical, apiculate, smooth, I I-I $4 \times 5-6 \mu$.

Under poplars in damp places, spring. France.

$\because \quad$ ** Pileus pale coloured.

connexifolia, Gillet, Rev. Myc., v, p. 30 (1883); Sacc., Syll. v, p. 771 ; Gill., Champ. Fr., with figure.

P. conical then somewhat spreading, margin always more or less recurved, obtusely umbonate, disc with fibrous adpressed scales, fawn-colour or pale reddish, 3-4 cm.; g. crowded, narrow, uncinnately adnexed, connected by numerous veins and anastomosing, colour of p.; s. solid, equal, fibrously squamulose, whitish or tinged red, 5-7 cm. sp. elliptical, smooth. Smell resembles fruit.

On the ground in woods. France.

Closely resembles $I$. pyriodora, differing mainly in the gills being anastomosing and conspicuously connected by ribs.

flava, Massee; Hebeloma flavum, Clements, Bọt. Surv. Nebraska, iv, 1896, p. 22 ; Sacc., Syll. xiv, p. 134.

P. campanulate, viscid, $5^{-6} \mathrm{~cm}$., edge incurved, appendiculate, pale yellow, with tawny subconcentric scales $2 \mathrm{~mm}$. broad; $\mathrm{g}$. somewhat sinuate, rather crowded, dingy; s. stout, solid, short, curved, yellow, densely covered except at the base with concentric, floccose, tawny scales, $3-5 \mathrm{~cm}$; sp. ovoid, smooth, $7-8 \times 4 \mu$.

On the ground. United States (Nebraska).

maculata, Boud., Bull. Soc. Bot. Fr., xxxii, p. 283, pl. 9, f. 2; Sacc., Syll. v, p. 775 .

P. campanulate then expanded and umbonate, rimose, covered with brown adpressed fibrils and ornamented with whitish adpressed squamules, mostly concentrically arranged, $3-5 \mathrm{~cm}$.; almost free, broad, fawn-colour with a tinge of olive ; g. solid, cylindrical, slightly thickened at the base, slightly fibrillose, colour of p., apex paler and scurfy, 3-8 cm.; sp. elliptic-oblong, smooth, 10-13 $35-6 \mu$.

In woods. France.

Near to 1 . rimosa, differing in the white scales on the pileus and larger spores. 


\section{Massee.-A Monograph of the genus Inocybe, Karsten.}

reflexa, Gillet, Champ. Fr., with figure (described in general index), 1897 .

P. convex, acutely umbonate, with concentrically arranged rows of fibrils, pale yellow, apex of umbo darker, $2-2.5 \mathrm{~cm}$; g. free, ochraceous; s. solid, smooth, yellowish above, base whitish, $5^{-8} \mathrm{~cm}$., very slightly flexuous ; sp. elliptical, smooth.

On the ground. France.

According to Gillet's figure the present species has a long slender wavy stem and an acutely conical pileus having two concentric ridges, which appear to be due to the cracking and upturning of the cuticle.

squamigera, Sacc., Syll. v, p. $763 ;$ Ag. (Ino.) squamiger, Britz., Hym. Sudbay., I 53 , f. $175(1883)$.

P. campanulate then expanded, umbonate, covered with minute squamules, saffron or dingy yellowish-red, edge wavy, $2 \mathrm{~cm}$.; g. adnate with a decurrent tooth, ventricose, brownish; s. equal, stuffed, flexuous, with rather.large fibrillose scales up to the annular zone, apex smooth, colour of p., 3-5 cm.; sp. elliptical, smooth, $8 \times 4 \mu$.

In woods. Bavaria.

Allied to $I$. hirsuta.

subgranulosa, Karst., Hedw., r892, p. 293 ; Sacc., Syll. xi, p. $5^{2}$.

P. convex then expanded, centre sometimes slightly depressed or obsoletely umbonate, even, pale ochraceous, with minute darker erect squamules, especially at the disc, or sometimes adpressedly squamulose, $2-4 \mathrm{~cm}$; g. adnate, seceding; crowded, greenish-cinnamon, then fuscous-cinnamon; s. stuffed then hollow; rigid, equal or narrowed below, curved or flexuous, with a minute subterranean bulb, a-3 cm. ; sp. smooth, 7-9 $\times 4-5 \mu$.

Sandy ground. Finland.

Very similar and also allied to $I$. delecta, Karst.

\section{IMPERFECTLY DESCRIBED.}

Under this heading are included those species where the general diagnosis is obviously inadequate, or where there is no mention of the spores. Such species may or may not belong to the genus Inocybe.

mammilaris, Sacc., Syll. v, p. 785 ; Ag. mammilaris, Passer., Fung. Parm., no. 189 , p. 76 .

P. white, convex, mammilose, squamulose; g. emarginately adnexed, edge white; s. white, hollow, equal, flexuous; sp. smooth.

On the ground. Italy.

grata, Karst., Hattsv., p. ${ }^{663}$; Sacc., Syll. v, p. 777 ; Ag. grafus, Weinm., Hym. Ross., p. I85.

P. fleshy, conico-campanulate, whitish rufescent: or rufescent, fibrillose, disc subsquamose ; g. olive, margin white, then olive-brown, adnered; s. equal, stuffed, fibrillose, colour of the $p$.

'Gregarious, somewhat fragile. Pileus at first conical. or conico-campanulate, whitish-fuscous or rufescent, almost plane when adult, $I-1 \frac{1}{2}$ ' lat. Gills $2^{\prime \prime}$ lat., 


\section{Massee.-A Monograph of the genus Inocybe, Karsten. 499}

somewhat crowded. Stem 2- $3^{\prime}$ long., 2-3" thick. Spores pale rusty-ochre 1 Odour pleasant I'

The above is Weinmann's description of his species, which differs very materially from that given by Fries and copied by Saccardo.

strigiceps, Sacc., Syll. v, p. 791 ; Ag. (Ino.) strigiceps, Fries, Epicr., p. 183; Ripartites strigiceps, Karst., Hattsv, p. 478.

P. obtusely convex then expanded, rufescent, strigose from the presence of long fibrils, silky, edge at first involute, ciliate with long deflexed fibrils, dry, I-2 cm.; g. adnato-decurrent, crowded, becoming brownish; s. stuffed, white, everywhere villose, $4-6 \mathrm{~cm}$.

Among fallen leaves in beech woods. Sweden, Holland.

capucina, Karst., Hattsv., $45^{8}$; Sacc., Syll. v, 772 ; Ag.(Ino:) capucinus, Fries, Vet. Akad. Förh., 1873 , v, p. 5 ; Fries, Icon. Sel., tab. 108, f. 2.

P. conico-campanulate, acute but not umbonate, dusky. brown, paler towards the margin, everywhere fibrillosely scaly, $2.5-5 \mathrm{~cm}$; g. sinuato-adnate, base broad and gradually narrowing towards the margin, brown; \&. solid, short, equal, fibrillose, brownish but paler than p., $2.5 \mathrm{~cm}$. Flesh white.

On the ground under alders. Sweden.

A section of the pileus is almost exactly an equilateral triangle.

The plant figured by Patouillard under the above name (Tab. Anal. Fung., no. $529)$ is obviously not the species of Fries, yet Saccardo has added to Fries' diagnosis of $I$. capucina the spore measurements of Patouillard's plant.

$?$ pollicaris, Karsten, Symb. ad Myc. Fenn., xi, in Meddel. Soc. pro. Faun. et Flor. Fenn., ix, p. 68 (1882); Sacc., Syll. v, p. 763 .

$P$. rather fleshy, campanulate then expanding muricate with squarrose squamules, brownish-bay, scarcely $1 \mathrm{~cm}$.; g. adnexed, crowded, ventricose, brownish-cinnamon (blackish when dry); s. equal, floccosely and squarrosely squamulose, colour of p., scarcely $3 \mathrm{~cm}$; sp. broadly elliptical, brownish, $3-5 \times 2-3 \mu$

In a hothouse. Finland.

Karsten places this species in the genus Inocybe with a query, but gives no reasons for so doing.

squarrosula, Sacc., Syll. xi, p. 50; Clypeus squarrosula, Karst., Symb. Myc. Fenn., xxxii, p. 7 .

$P$, convexo-plane, obtuse, fibrillose, fuscous, disc with squarrose squamules, darker, I-2 cm.; g. crowded, subventricose, brownish, white-crenulate; s. equal, brownish squamulose, $2-3 \mathrm{~cm}$.; sp. $10 \times 7-8 \mu$.

On pine trunks. Finland.

gomphodes, Sacc., Syll. v, p. 786 ; Ag. (Iro.) gomphodes, Kalchbr., Grev., viii, p. $1_{52}$, tab. $1_{4} 2$, f. 8 .

P. campanulate with a pronounced globose umbo, fbrillose, brownish, $1 \cdot 5^{-2} \mathrm{~cm}$. ; g. ascending and almost free, narrow, greyish umber; s. stuffed, subequal, pallid rufous, base slightly bulbous and surrounded with white mycelium.

New South Wales (Richmond River).

Readily distinguished by the globose umbo nearly the size of a pea, perched on the top of the campanulate pileus. 


\section{Massee.- $A$ Monograph of the genus Inocybe, Karsten.}

delecta, Karst., Hattsv., i, p. 460; Sacc., Syll. v, p. 783 ; Ag. (Ino.) caesarialus var. fibrillorus, Fries, Icon. Sel., tab. 109, f. 3.

P. convex then plane, scarcely depressed or umbonate, fibrillosely scaly, dingy, tawny- or rufous-honey-colour, pale rufous-cinnamon when dry, about $5 \mathrm{~cm}$.; $\mathrm{g}$. emarginate, crowded, ventricose, pale honey-colour then with an olive tinge, finally brownish, edge paler and crenulate; s. solid, equal, slightly curved, dingy yellow or rather pallid, white fibrillose, apex nearly naked, 3-5 cm. Flesh yellowish then white.

Near paths in pine woods. Sweden, Finland.

viscosissima, Karst., Hattsv., p. 465 ; Sacc., Syll. v, p. 789 ; Agaricus viscosissimus, Fries, Icon. Sel., ii, p. 9, tab. I Iо, f. 2.

P. persistently convex, acutely umbonate, brownish umber, very glutinous then silky, 2-2.5 cm.; g. rounded behind and almost free, ventricose, rufescent ; s. subfistulose, equal, glabrous, pallid, not fibrillose but usually white-pruinose, $3-4 \mathrm{~cm}$.

On the ground in pine woods. Sweden.

Allied to $I$. Irechispora, but differs in the colour of the pileus, and the glutinous coating, which is present in sufficient quantity to drip to the ground. Quélet (Flor. Myc. 102) gives the present species as a synonym under his $I$. umbonata. This however cannot be correct, as the last-named Fungus has the stem floccose up to a distinct ring, and is obviously a Stropharia.

\section{EXCLUDED SPECIES.}

umbonata, Quél., Bull. Soc. Bot. Fr., i876, p. 330, pl. 2, f. 4.

This is undoubtedly a species of Stropharia with the stem floccosely peronate up to the ring. It was originally called Agaricus (Stropharia) inunctus, Fr., by Quelet (Champ. Jur. et Vosg., i, p. I 10).

psamminum, Sacc., Syll. xi, p. 5o (foot-note); $A g$. (Heb.) psamminus, Berk.

This species is a Flammula, and will stand as $F$. psammina.

plumosa, Karst., Hattsv., p. 455 ; Sacc., Syll. v; p. 763 ; Ag. (Ino.) plumosus, Fries, Mon., i, p. 337 ; Ag. plumosus, Bolton, Hist. Fung., i, p. 33, pl. 33 (1 788 ).

On carefully going over Bolton's description of his Fungus, I can find no justification for its retention in the genus Inocybe. He distinctly states that the gills are white, both in his Latin diagnosis, and in his general description of the species. On this point Bolton can be trusted, judging from his usual accuracy in colour descriptions.

. It was Fries who first suggested that Bolton's plant belonged to the section Inocybe, and described the gills as 'albido-fuligineis,' and most people have accepted the description given by Fries of what he supposed to be Bolton's. Fungus.

No one in Britain has found an Inocybe corresponding to Bolton's figure and description since Bolton's time. I am inclined to think that the Fungus Bolton had in view was a species of Collybia of the section Vestipedes.

The following is Bolton's description of the Fungus under consideration :-

'Agaricus stipitatus, pileo hemispherico plumoso murino, lamellis trifidis albidis stipite longo plumoso.'

"The root is round, hard, the size of a pea, of a brownish-black colour, and emitting a few long hard fibres; it is not surrounded by a volva. 


\section{Massee.-A Monograph of the genus Inocybe, Karslen. 501}

'The stem is hard, solid, cylindrical, often bended or waved, the' thickness of a duck's quill, and about four inches bigh; it is closely covered with small downy or feathery tufts of a perfect mouse-colour; there is no curtain.

'The gills are in three series, deep, and terminate in a claw at the base, which just touches the top of the stem ; they are numerous, soft, Alexible, white, and of a dry, light substance.

' The pileus is hemispherical, an inch and a half in diameter, of a perfect mousecolour, and like the stem, thickly covered with little tufts of a downy matter, which grow from its surface, and are of the same colour with it; there is a beautiful fringe of the same down all round the margin. The substance is thin, light, dry, and flexible ; it withers in decay.'

micropyramis, Sacc., Syll. xi, p. $5 \circ$ (foot-note); Ag. (Heb.) micropyramis, Berk.

This is a Naucoria, and will stand as $N$. micropyrama (Berk.).

subroindica, Bann. and Peck, 44 Rep. State Mus., p. 70; rubroindica, Sacc., Syll. xi, p. $\mathbf{5}^{2}$.

Only described from a sketch. No mention of spores, and no published figure.

tricholoma, Sacc., Syll. v, p. 790; Ag. tricholoma, Alb. and Schw., Consp., p. 188.

This has been correctly referred to Flammula by Karsten, on the label to '.Karst., Fung. Fenn., exs. 41 2.'

violaceafusca, Sacc., Syll. ix, p. 96; Ag. (Ino.) violaceafuscus, Cke. and Massee, Grev., xvii, p. $5^{2}$; Cke., Ill., pl. I 74 .

This proves to be a Cortinarius, and will thus become $C$. (Dermo.) violaceafuscus, Cke. and Massee.

phaeocephala, Sacc., Syll. v, p. 774 ; Ag. phaeocephalus, Bull., Champ. Fr., tab. 555, fig. I ; Ag. (Ino.) phaeocephalus, Fries, Hym. Eur., p. 231 ; Cke., Hdbk., ed. ii, p. 155 ; Cke., Ill., pl. 396.

I can find no justification for the retention of this species in Inocybe. It was first placed there by Fries, who never saw what he considered to be that species, but drew up his diagnosis from Bulliard's figure, adding a rider to the effect that its position is doubtful. Cooke's description with a 'smooth pileus' and 'bright ferruginous spores' certainly does not suggest Inocybe.

schista, Sacc., Syll. v, p. 774 ; Ag. (Ino.) schistus, Cke. and Sm., in Cke., Hdbk., ed. ii, p. 154 ; Cke., Ll., pl. 504.

P. campanulate, broadly subumbonate, cracking longitudinally, rather fibrillose, bay-brown, 5-8 cm.; flesh thin, equal, dingy like that of the s.; g. adnate with a decurrent tooth, rather ventricose, broad, tawny-rufous at maturity, edge pale, serrulate; s. solid, equal, twisted, paler than p., $6-8 \mathrm{~cm}$.

Among short grass. Britain.

A species founded entirely on a sketch, which may or may not have been accurately done in the first instance.

tomentella, Sacc., Syll. v, p. 783 ; Quél., Fl. Myc., p. 106 ; Ag. (Ino.) tomentellus, Fries, Epicr., p. 176; Ag. tomentosus, Jungh., Linn., 1830, p. 403, tab. v, f. 7 ; (not Bull. nor Bolton).

This does not belong to the genus Inocybe. It may be an Hebeloma. Fries, who M $\mathrm{m} 2$ 


\section{Massee.-A Monograph of the genus Inocybe, Karsten.}

first placed it in Inocybe, did not see a specimen, but simply copied Junghuhn's description, says :- ' facie Hebelomatis insignis.'

imbecillis, Sacc., Syll.v, p. 790 ; Ag. (Ino.) imbecillis, Fries, Hym. Eur., p. 236 ; Ag. imbecillis, Passer., Fung. Parm., p. 76.

Too imperfectly described to be referred to any genus except as a pure speculation.

\section{. \\ DESCRIPTION OF FIGURES IN PLATE XXXII.}

Illustrating Mr. Massec's monograph of Inacybe.

Fig. I. Section throngh portion of gill of Inocybe geophylla, Karst. a, a, basidia bearing spores in different stages of development. $b, b$, basidia. $c$, paraphyses. $d$, subhymenial hyphae. $c, c$, hyphae of trama. $\times 500$.

Fig. 2. Tnocybe rhombosfora, Massee. Nat. size.

Fig. 3. Spores of same. $\times 400$.

Fig. 4. Spores of same, very highly magnified. One spore shows surface and the other lateral view.

Fig. 5. Inacybe Buckmalli, Massee. Nat. size.

Fig. 6. Rasidia and spores of same. $\times 500$.

Fig. 7. Cystidium of Inocybe grophylla, Kant, showing sphere of mucilage extended from its apex. $\times 500$.

Fig. 8. A per of cystidium after the sphere of mucilage has contracted and formed a brownish mass of crystalloids. $\times 500$.

Fig. 9. Cystidium showing a dense mass of spores held together by the sphere of mucilage extended from its apex. $\times 500$

Fig. ro. Fusiform or fasoid type of cystidinm. $\times 500$.

Fig. II. Inacybe Gaillardi, Gillet, single spore of. $\times 500$.

Fig. 1 2. Trocybe calospora, Quél., single spore of. $\times 500$.

Fig. 13. Thin-walled cell from margin of gill of Imacybe Buckralli, Massee. $\times 500$. 

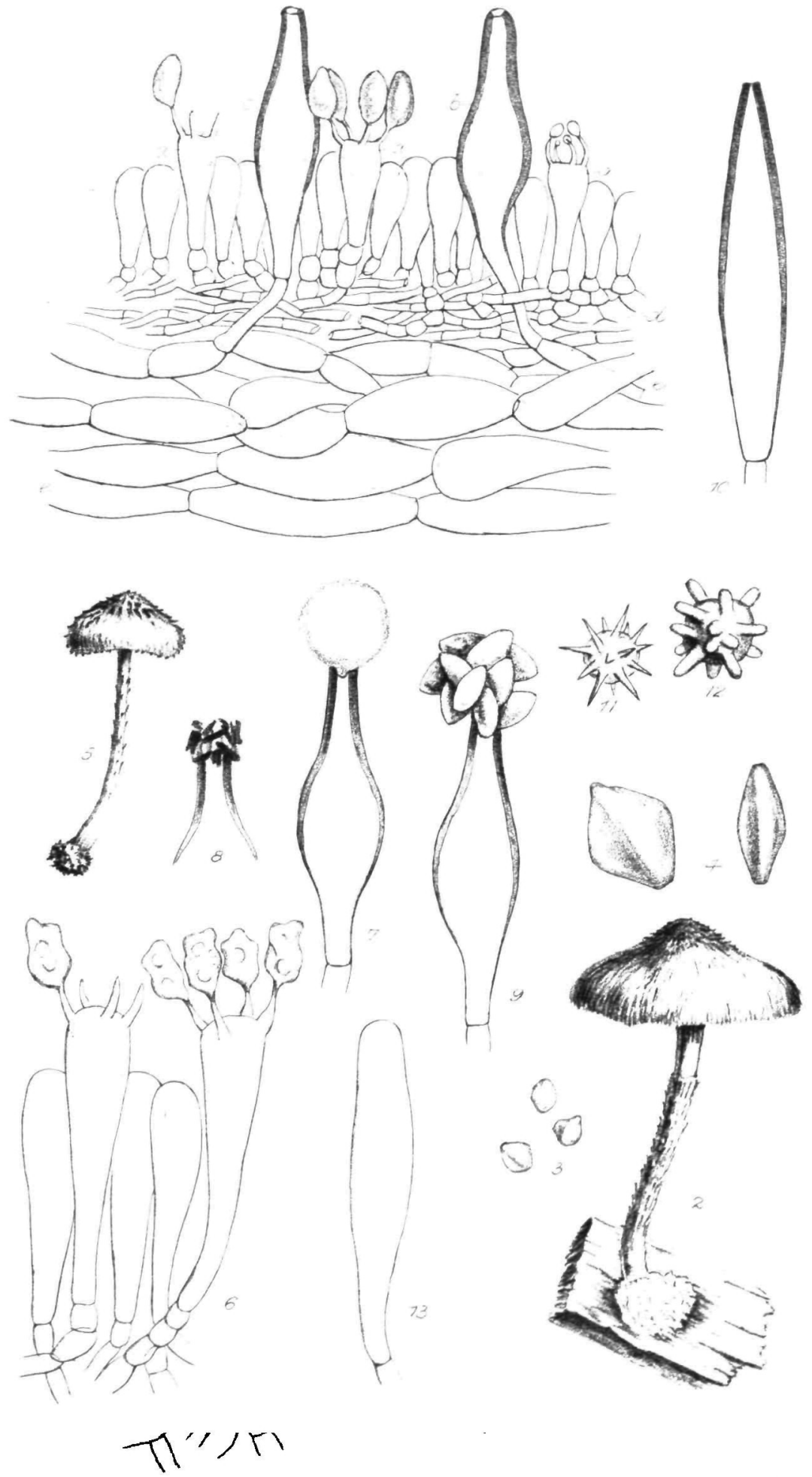

Highley. Litruetimp.

G.Mussee del. MASSEE. Chanutos of hymenturnin Inoute 
,

Downloaded from https://academic.oup.com/aob/article-abstract/os-18/3/459/170393 by University of California, Santa Barbara user

on 09 March 2018 


\section{Massee.-A Monograph of the genus Inocybe, Karsten. ${ }_{503}$}

\section{INDEX.}

Inooybe, 463.

abjecte, Karst., 480 .

agglutinata, Peck., 478 .

albipes, Gill., 473.

albodisca, Peck., 466.

asinina, Sacc., 474.

asterospora, Quél., $4^{6} 5$.

Bongardi, Karst., 489.

Bresadolae, Mass., 465 .

brannea, Qael., 486.

Bucknalli, Mass, 473.

caesariata, Karst., 482.

calamistrata, Karst., 493 .

calospora, Quél., 469.

capucina, Karst., 499 .

cârpta, Sacc., 483 .

cervicolor, Quél., 479.

cicatricata, E. and E., 467.

cincinnata, Karst., 48 g.

Clarkii, Sacc., 477.

comatella, Peck., 487 .

commixta, Bres., $4^{6} 7$.

concinna, Karst., 480 .

conformata, Karst., 488.

confusa, Karst , 480 .

connexifolis, Gill., 497.

Cookei, Bres., 492.

cortinata, Roll., 476.

corydnlina, Quél., 477.

var. roseola, Pat., 477.

cocollata, C. Mart., 496.

Curreyi, Sacc., 495.

curvipes, Karst., 467 .

decipiens, Bres, 467 .

deglubens, Karst., 479.

var. trivialis, Kerst, 479

delecta, Karst., 500 .

descissa, Karst., 478.

destricta, Karst., 480.

dolcamara, Karst., 488.

echinata, Sacc., 493.

echinocarpa, $\mathrm{E}$ and $\mathrm{E}, 470$.

criocephala, Sacc., 466.

erythroxn, De Seynes, 494.

eutheles, Sacc., 476.

entheloides, Peck., 485.

fasciate, Sacc., 468.

fastigiata, Karst., 495.

fibrillose, Peck., 491.

fibrosa, Karst., 464. flava, Mass., 497.

flavella, Karst., 4 Sa.

flocculosa, Sacc., 487.

frimentacea, Bres., 486.

fuegiana, Sacc., 490.

fulvella, Bres., 472.

fumosapurpurea, Lasch., 493.

fuscodisca, Mass, 487.

Gaillardi, Gill, 470.

geophylla, Karst., 477.

var. fulva, Pat., 478.

var. violacea, Pat., 478.

Godeyi, Gill., 48I.

gomphodes, Sacc., 499.

grammata, Quél., 473.

grata, Karst., 498.

griseoscabrosa, Mass., 484.

haemacta, Sacc., 486.

haemaiophylla, Berk., $493^{\circ}$.

hirsuta, Karst, 492.

hirtella, Bres., 474

hiulca, Kalchbr., $48 \mathrm{I}$.

bolophlebia, Sacc., 490.

Hookeri, Klotesch., 493.

hystrix, Karst., 483.

ignobilis, Sace., 472.

Imbecillis, Sacc., 502.

incamata, Bres., 484.

inedita, Sacc., 464.

infelix, Peck., 479.

infida, Mass., 467.

jurana, Pat., 486.

lacera, Karst., 483.

lanuginosa, Karst., 468.

Leucocephala, Boud., 467 .

lacifaga, Karst., $48 \mathrm{r}$.

maculata, Bond., 497.

mammilaris, Sacc., 498.

margarlspora, Sacc., 473.

meritima, Karst., 471.

maritimoides, Peck., 469.

Merletii, Quél., 497.

mimica, Mass., 492.

murino-lilacina, E. and E., 495.

matata, Mass., 496.

mutica, Sacc., 485.

nigrodisca, Peck., 485.

obacura, Karst., 481.

pallidipes, E. and E., 476.

paludinella, Sace, 468.

perbrevis, Karst., $49^{\circ}$. 
growth being obliquely ascending. In the later growth of these branches the tips become vertical, and on leaving the soil they continue their growth as aerial shoots.

In branches of type (2) Bertrand ('81, p. 265) regards each lateral apex as being an. arrested and laterally displaced branch of a dichotomy, the other branch having continued its growth and appearing like the direct continuation of the parent branch ${ }^{1}$. The growth is therefore described by Bertrand as sympodial. He also ('81, p. 274, \&c.) regards some parts of the plant, e. g. certain aerial shoots and branches of category (3), as being 'cladodes,' produced by a a.kind of cóhesion or fasciation of ordinary branches, founding this view partly on the structure of the stele. These views are referred to by Solms-Laubach. ('84, p.: I 57) and need not be entered into further here.

For the purpose of the present description it will be sufficient to distinguish between the different parts as follows : $(a)$ aerial stem ; $(b)$ ordinary rhizome; including branches of types ( $\mathrm{r}$ ) arid (2); (c) type (3) described above, thaving characters'transitional between rhizome and aerial stem; 'this may be called the stock of the aerräl stem. The nature of the transition makes it impossible in some cases' tô draw any sharp limit between the stock of the aerial steni ând the ordinày rhizome, or even to classify some of the olde: branches. ${ }^{2}$.

In Bertrand's work the results are given of an elaborate investigation of the structure of Psilotum. "The figures illustrating this work may be referred' to for the primary structure of the stele. Thus Fig. I 34 (p. 298) shows the stele of some very delicate branches of the rhizome, having only a small number of tracheides in the xylem, namely four, three, two and one respectively.

A transiverse section of a branch of the rhizome having only three tracheides is shown in Fig. 45 in the text in the present paper: The stele of a stouter branch of the rhizome is reproduced in .Fig: I, PI. XXXIII; here nine tracheides' are seen ${ }^{3}:$ ' In the ordinary rhizome the number of tracheides in the stele varies greatly with the diameter of the organ. When only a few tracheides are present, there may be no clearly marked protoxylem, but when the tracheides form a larger group the xylem often takes the form of a diarch plate. Fig. 46 in the text shows an incompletely differentiated diarch plate ${ }^{s}$ of eleven elements, of which five tracheides only are lignified. Here, and in other cases (e. g: at the base of the aerial shoot),

${ }^{1}$ Solms-Laubach $\left(84\right.$, p. $\left.15^{8}\right)$ however found that true lateral branching occurred in addition to this type of growth.

In doabtful cases the stumps of rhizoids, which have fallen off, give some clupe by their abandence or otherwise.

- Seven are distinct, and there are two pale ones on the left.

- See Bertrand (81), Figs. I 35 and 136.

- Differentiation appeared to have been arrested. 
where the protoxylem is clear, it is evident that the differentiation of the primary xylem is centripetal in the rhizome and in the stock of the aerial stem.

At the base of the stock of an aerial branch the xylem is often diarch, as in many of the larger branches of the rhizome, but when traced upwards (acropetally) the stele gradually increases in size and becomes triarch; above the soil the exarch stele continues to enlarge, becoming successively tetrarch, pentarch, and so on, up to e.g. octarch, but, during this enlargement of the xylem, sclerenchyma (preceded by a little parenchyma) has appeared within it in a central position, and has increased to a large central group, so that the tracheides now form a hollow many-rayed exarch star enclosing this group of sclerotic tissue ${ }^{1}$. Figures illustrating the form or structure of the stele of the aerial stem are given by Brongniart ('37, P1. XI, Fig. I), Link ('42, Fasc. IV, Taf. V, Fig. I), Nägeli (58, Pl. I, Fig. 3), Bertrand (81; Fig. $174,8 \mathrm{cc}$ ), and Pritzel ('00, Fig. $3^{83} \mathrm{~A}$ ).

So far all that has been said refers to the primary structure of the stem, and nothing besides this is to be seen either in Bertrand's figures of the rhizome and aerial stem, or in the illustrations of the other authors referred to. In certain parts of the plant however, when examined at a sufficiently late stage, additional tracheides are found to be present. They will be described below as secondary, and the reasons for regarding. them as such will be given later.

In Fig. I, Pl. XXXIII, which is a transverse section of the rhizome with primary structure only, one sees a zone of 'parenchyma ${ }^{2}$ ' often three to four cells thick between the centrally placed group of xylem-elements and the zone of sieve-tubes ${ }^{3}$, the position of the latter being given at $s . t$. A similar zone of parenchyma is found in a corresponding position in the stock of the aerial shoot and also in the aerial shoot itself (though here often reduced opposite the protoxylem groups). The primary xylem is generally composed of a solid mass of tracheides, not interrupted by parenchyma, though this is not without exception, and the development is centripetal.

An examination of the stock, of the lower part of the aerial shoot, and of some parts of the ordinary rhizome (in each case when old) showed additional

' Redaction of the stele through somewhat similar steps accompenies its decrease in size throngh successive branches of the aerial stem.

2 Thin-walled considerably clongated elements.

- A careful examination of these elements was not made, but it may be mentioned that, in the presence of numerous granules clinging to the walls, they resemble the Fern-type, that they are present in the rhizome as well as in the aerial stem, although De Bary ('77, p. 349) failed to find them in the former. In the rhizome and stock of the aerial stem they form. an interropted ring, single sieve-tubes and also tangential rows of two or three siere-tubes being separated by parenchyma: In the aerial stem they may form a thicker rone. There are no special gaps opposite the protoxylems; see Russow ("76, p. 40), where he corrects the mistake as to their distribation shown by his carlier figure ("72, Taf. XI, Fig. 30). 
tracheides, to be regarded as secondary, scattered in the zone of parenchyma referred to above ${ }^{1}$, and hence outside the mass of tracheides forming the primary xylem. These additional tracheides are mostly separated by at least one layer of parenchyma from the central group, but some of them may be in contact with it. They are only to be found in old parts of the plant, where they may show all stages of differentiation, but in the oldest parts examined ${ }^{2}$ all the secondary tracheides present were completely lignified.

Figs. $2-6$ in Pl. XXXIII show secondary tracheides in the tissue surrounding the primary xylem. Text-Fig. 44 is an external view of the stem from which these sections were cut. In this figure, $e, f$, and $g$ are three aerial shoots, and it is clear from the disposition of the parts that $e$ must have been the first-formed aerial shoot, and that from its lower region an obliquely ascending branch $(c, d)$ grew out on the right and gave rise to the two other aerial shoots $f$ and $g$.

The whole of the branch $c, d$ should perhaps be classed as the stock of the aerial shoots, the lower part certainly so, but, on the right beyond the point of insertion of $f$, it becomes rhizome-like again, as evidenced by reduced diameter, remains of rather numerous rhizoids, and by the character of the stele. A transverse section from this region, cut at the level of $d$ in Text-Fig. 44, is represented in Fig. 2, Pl. XXXIII. It will be seen that there is a centrally placed group of tracheides $(p)$, probably diarch, which is comparable with the primary group in Fig. I, Pl. XXXIII, though the size and number of the elements differ. In Fig. 2 the central group of primary tracheides $(p)$ is surrounded by a considerable number of smaller tracheides, which are to be regarded as of secondary origin. Several of these elements have much darker walls than the tracheides of the primary group. This is due to the colour-differentiation of the stain employed (methyl-green and eosine), all incompletely lignified walls having taken up eosine as well as methyl-green, the combination of the two stains producing a purple colour, which is in strong contrast to the green or blue of the fully lignified elements. Watery methyl-green followed by alcoholic eosine proved a very satisfactory stain for differentiating such partially lignified elements ${ }^{3}$. Phloroglucin with hydrochloric acid was used for comparison; two consecutive sections were chosen, and one was stained with methyl-green and eosine, the other with phloroglucin. A close correspondence was shown; the elements which stained purple or purplish black with the double stain being just those which only stained faintly with phloroglucin, while all the

1 Or largely replacing it.

2 Probably one year or more old. Proportional age may be estimated by the amount of the pell-known brown substance, which encroaches on and gradually fills op the cavities of many of the cells of the inner cortex, and by the hardness of the specimen. An old branch of the rhizome showed weven primary and twenty secondary tracheides, all mature.

This stain was ased for the same purpose in Ophioglassum (Boodle, '99, p. $3^{86}$ ). 


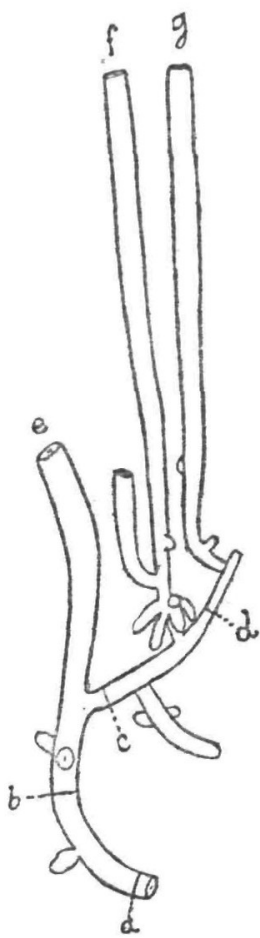

FIG. 44 .

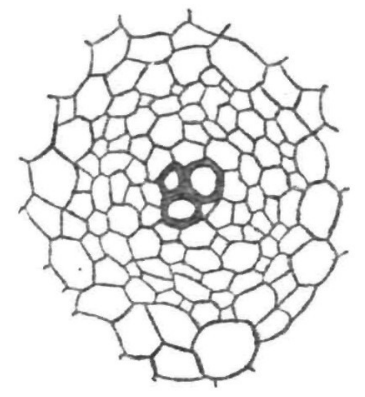

FIG. 45 .

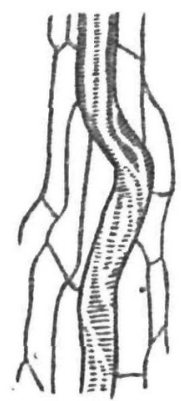

FIG. 47 .

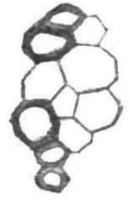

FIG. $4^{6 .}$

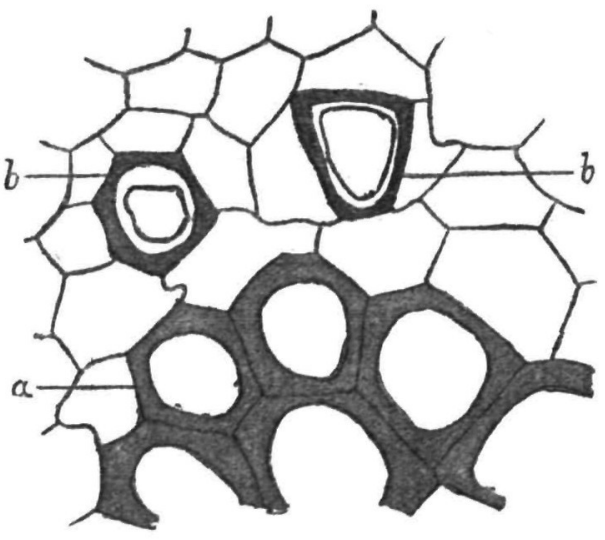

F1G. 49.

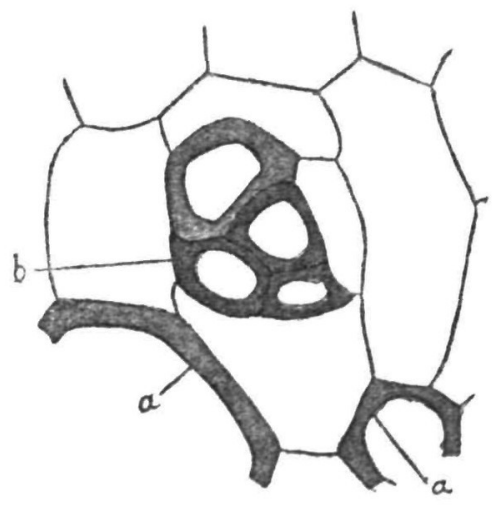

FiG. 50.

FIG. 44. Specimen from which numerous sections were cut. $c, s$, and $g$, three aerial branchet. About natural size. FIG. 45. Stele of small branch of rhizome in transverse section. There are only three tracheides; sieve-tubes not specially indicated. $\times$ 95. FiG, 46. Diarch xylem of stele of a rhizome, arrested in development. $x$ 95. FrG. 47. Part of a secondary tracheide showing a constriction. $x$ 390. FIG. 48. Scalariform secondary tracheide showing sinuous conrse. $\times 95$. FIG. 49. From a transverse section through the basal part of the aerial branch $g$, in Fig. 44 , primary tracheides; $b, b$, eccondary tracheides, incompletely lignified and containing a protoplasmic lining. $x$ 390. F1G. 50. Group of four secondary tracheides (b), with parts of two primary tracheides (a) and adjacent parenchyma. This gronp is seen at $s$, in Fig. 3 in the plate. $\times 390$. 
blue or green walls in the first preparation showed full coloration with phloroglucin in the other.

Fig. 3, Pl. XXXIII, is a section cut at the point marked $c$ in Fig. 44 in the text. It shows a conspicuous band of primary tracheides and a large number of smaller secondary tracheides, among which one group of four, marked $s$ in this figure, is drawn further enlarged in Text-Fig. 50. The three elements with the darker walls are incompletely lignified.

Fig. 4, 5, and 6 in Pl. XXXIII are transverse sections of the stock of the aerial branch $e$ in Text-Fig. 44, cut at three levels in ascending order. Their positions are indicated by letters : $a$ is the level of Fig. $4, b$ that of Fig. 6 , and about half-way between $a$ and $b$.is the position of Fig. 5. In these three sections numerous secondary tracheides are present, many of them being incompletely lignified. In Fig. 4 the primary xylem can be recognized as a broad plate of tracheides. In Fig. 5 the xylem has become roughly triangular, and at $r$ a parenchymatous ray is seen running inwards as far as one of the protoxylem-groups, in which there is a crushed tracheide. In Fig. 6 the primary xylem-group is considerably larger than in Fig. 5, triangular and doubtless triarch. At several points outside the primary xylem, e. g. at $r$, radial arrangement is found among the parenchyma and secondary tracheides.

Fig. 49 in the text is from a transverse section through the lower part of an aerial shoot. It shows some primary tracheides $(a)$, and two secondary tracheides $(b, b)$. The latter are incompletely lignified, and still contain a protoplasmic lining. Similar cases were met with in many of the sections.

The nature of the secondary tracheides may now be referred to. They are scalariform, or sometimes rather irregularly pitted, and they frequently have a sinuous course, while the primary tracheides are generally straight. This must be due to their having to push their way among mature parenchyma, \&c., by sliding growth. Fig. 47 in the text shows a secondary tracheide with a constricted part, probably owing to some of the adjacent elements having resisted compression more than others. The secondary tracheides frequently occur in groups similar to that seen at $s$ in Fig. 3, Pl. XXXIII, and often one or two of the parenchymatous cells immediately adjoining such groups have become partially or completely collapsed ${ }^{2}$. Fig. 48 in the text is a scalariform secondary tracheide showing its sinuous course.

From the material examined it cannot be definitely stated how high up in the aerial stem secondary tracheides may occur, but in one specimen several were present in a stele containing a fair-sized central group of sclerenchyma.

The examples of the occurrence of secondary tracheides chosen for illustration in Pl. XXXIII do not include any case in which it was perfectly clear that the organ in which they were present should be, classed as

1 The rigidity of the cortex preventing expansion of the stele. 
ordinary rhizome, since the nature of the branch, shown in section in Fig. 2, might be disputed. Examples were found, however, in which true rhizome branches attached to the stock of an aerial shoot contained a few secondary tracheides ${ }^{1}$.

We must now discuss the reasons for regarding the outer tracheides as secondary. An important point is the late differentiation of the earliest of these elements. If one takes the case of the stock of an aerial shoot with diarch structure, the xylem differentiates centripetally until complete, and there appears to be a considerable pause before the outer tracheides arise. In this. respect. the fact is significant that Bertrand does not appear to have seen secondary tracheides in any. part of the plant. This appeared so remarkable that the question suggested itself whether the production of these elements might not be exceptional and dependent on special conditions of growth, or perhaps shown only by one variety of the species. This however is improbable, because .I learn from Miss S. O. Ford and from Miss E. N. Thomas that they also have found these elements. Hence it is probable that Bertrand did not examine material of suitable age. At what distance from the apex they.first begin to develop could not be determined.

Another fact suggestive of secondary growth is that successive differentiation of these tracheides is still proceeding in quite old parts of the subterranean stem, a long way back from the aerial branch. Thus at $a$. in Fig: 44 in the text, differentiation is still going on, and the basipetal distance of this from the cut end of the aerial branch $g$ (where 'primary' development is complete) amounts to about $10 \mathrm{~cm} .^{8}$. The stem at $a$ is probably several months old. There is nothing to suggest that the apparently developing tracheides are permanently arrested immature elements, since the outer tracheides in the oldest stems examined were all mature, and true arrest in the metaxylem of one branch showed quite different characters.

No definite cambium is present, but radial arrangement is often shown to a slight extent: In Fig. 6, Pl. XXXIII, r marks a radial row of five elements, all parenchymatous except the outermost one, which is a young tracheide containing protoplasm. In a few cases parenchymatous rays occur opposite the protoxylem-groups; a rather good case is seen at $r$ in Fig. 5. These last two features, though not particularly well marked here, are familiar characters of secondary xylem.

Taking all these facts into consideration one is justified in assuming that the late-formed tracheides represent a comparatively slight amount of secondary xylem, and that this is probably a reduction from more normal secondary thickening is suggested by the fact that in Psilotum the leaves

1 In other cases, where the branches were older and their rhizomic nature less certain, numerous secondary tracheides were present.

2 Several centimeters of branched stem had been cut away above $g$. 
have been reduced to scales, whereby reduction of transpiration must have been achieved.

The mode of occurrence of the secondary tracheides appears to point to the plant having retained the power of forming such additional elements in consequence of the necessity for an adequate water-conduction or waterstorage capacity in branches, on which the water-supply of well-developed aerial shoots devolves. The stimulus, which leads to the differentiation of the secondary tracheides, may perhaps be either some secondary effect of increased transference of water caused by the transpiration of the aerial shoots, or the backward conduction of carbohydrates from the latter.

The specimen shown in Fig. 44 in the text presents some instructive features in relation to this. Secondary tracheides are present in the base of the aerial shoot $g$, throughout the branch $(d, c)$ bearing it (though decreasing between $d$ and the insertion of $f$ ), and downwards in the parent stem to the base of $b, a$. This may well be due to a backward stimulus from the shoots $f$ and $g$. The other aerial shoot $(e)$ had evidently been cut or broken off at $e$ when young. In its upper region primary differentiation had been arrested before completion, but in its lower region, though primary differentiation was complete, there were no secondary tracheides. In tracing the structure upwards in the stock of this branch from $b$ towards the point where $c, d$ was given off, it was interesting to find the secondary tracheides gradually becoming restricted to one side of the stele, so that when the branching took place they all accompanied the stele supplying $d, c$. This disposition certainly favours the supposition of a basipetal stimulus.

If one adopts the view that the outer tracheides represent reduced secondary xylem, the correspondence between the stem-structure of some parts of the plant in Psilotum and that of Sphenophyllium becomes rather striking. Setting minor details aside, the triarch xylem-mass surrounded by a small amount of secondary xylem in a young stem of Sphenophyllum (Scott, '00, Fig. 35, p. 85, and Williamson, '74, Pl. I, Figs. 2-4) compares well with the structure of the stock of an aerial sten of Psilotum seen in Fig. 6, P1. XXXIII. The structure of the aerial stem of Psilotum with its stellate xylem bears a strong resemblance to that of the axis of Cheirostrobus ${ }^{1}$, but there is the difference that in Cheirostrobus the tracheides form a solid star, while in Psilotum the more central part of the xylem has been replaced by sclerotic tissue. Comparison of rhizomes cannot well be made, as an organ of this kind is not known with certainty in Sphenophyllum, and the rhizome of Psilotum may perhaps have been greatly modified by

'See Scott, '97, P1. I, Phot. 3. Cheirostrabus most resembles Sphenophyllum, thongh it sheres certain characters with Lycopods and Calamartans. See Scott, '97, p. 26, \&c. : We may hazard the inference that Cheirostrobus as well as Sphenophyllum sprang from a very old stock, which existed prior to the divergence of the Lycopods and Calamarians.' 
reduction in consequence of its saprophytism. Dr. Scott, however, kindly gives me the information that organs with indeterminate xylem are sometimes associated with specimens of Sphenophyllum, and may possibly prove to be the rhizome of that plant.

Thus in structure the base of the stem of Psilotimm recalls the stem of Sphenophyllum, while the upper part of the stem resembles the axis of the cone of Cheirostrobus, a plant with some relationship to the Sphenophylleae.

This amount of structural agreement ${ }^{1}$ owes its value to the fact that the sporophylls of the plants concerned show distinct relationship of type. The correspondence of the typical synangium of the Psiloteae (Tmesipteris and Psilotum), together with its pedicel, to the sporangiophore of the Sphenophylleae was pointed out by Scott ('97, p. 27, and '00, p. 499), and this correspondence was found by Thomas ('02) to become, on the whole, still closer in the case of variations of the sporophylls of Tmesipteris to a presumably more primitive type ${ }^{8}$. The whorled arrangement of the leaves in the Sphenophylleae is a marked point of distinction from the Psiloteae. This and the nature of the sporophylls and the other characters of these two orders are discussed by Bower ('03, p. 227 et seq.), who adopts the hypothesis of the relationship, and further agrees with Thomas that the Psilotaceae should be included in the group Sphenophyllales.

It must be mentioned here that Lignier ('03, p. I06, \&c.) holds the view that the Tmesipterideae or analogous types are among the ancestors of the Sphenophyllales, but he intercalates a Filicinean type between the two. Lignier ('03, p. 105) also assumes as probable the presence of secondary xylem and phloem in the ancient Filicinean types, so that on this supposition the presence of secondary thickening in living Psilotaceae and the deduction of its existence in their remote ancestors would not be discordant with Lignier's hypothesis of the phylogeny.

- In view of the fact that modifications of rascular structure can readily take place, the ralue of soch resemblances between a recent plant and an ancient type may appear very small, but that well-defined details of primary stracture may be retained for long ages is generally admitted and is well illustrated by the case of Equisetum and the Calamariene. The value of secondary xylem as a character must be admitted to be much less, especially as secondary thickening appears to have been so general among vascular plants in the coal-measures. In a case of this kind, however, every additional point of agreement has some value, and, further, the presence of secondary growth may be teken as suggesting affinity with encient types. of vascalar cryptogams. As a parallel case Isoetes may be quoted, in which the presence of secondary thickening helps the view of affinity with the Lepidodendreae. In a genus like /saetes, in which a large number of species are submerged equatics, the presence of secondary thickening is rather sarprising, and the same is the case in a less degree for Prilotum with its reduced transpiring surface. That is to way, in both cases there is 2 probability against the secondary growth being a recent acquirement.

- Namely brenched sporophylls and formation of extra sporangiophores. Bower C03, pp. 228 , 229) regards these as not reversional, bat as cases of increased complexity due to favonrable nutrition as the determining factor (in this respect agreeing with Thomas's view), bat corresponding to 'morphological possibilities of further amplification.' 
A short comparison of the structure of Psilotum and Tmesipteris is called for here. No secondary growth is known in Tmesipteris. It is possible that it may yet be found in old parts of luxuriant plants, or on the other hand it may have been quite lost by reduction. In Tmesipteris the lower part of the stem, which is covered with rhizoids, may be called rhizome; the structure exhibits much the same type as the primary structure of the same organ in Psilotum. The xylem of the stele consists of a solid group of tracheides, either with no distinct protoxylem in the case of small steles, or exarch and diarch in larger ones ${ }^{1}$. At the base of the 'aerial' stem of Tmesipteris the stele has a solid triangular group of xylem with three protoxylem-groups (see Dangeard, '91, PI. XII, Fig. IO), and agrees with that of Psilotum (in the same region), except that the xylem is mesarch in Tmesipteris.

In the aerial stem also Tmesipteris has mesarch structure. A less important point of difference is that the xylem takes the form of a number of separate strands surrounding a sclerotic pith. Such a structure might easily be attained in Psilotum by the suppression of the later-formed part of the metaxylem, and this had actually taken place by arrest in the upper part of the aerial branch $e$ (Fig. 44 in the text), there being five separate groups of xylem, each with its protoxylem.

The other distinction between the two genera, viz. the absence of mesarch structure in Psilotzm, is apparently not absolute, though further investigation is desirable on this subject. Cases of apparent mesarch structure were certainly met with locally in the lower part of the aerial stem ${ }^{3}$, a small number of scalariform tracheides being found on the outer side of one or more of the protoxylem-groups. The difficulty here is to prove that these elements are not secondary, and the material was not quite sufficient for the purpose. It may be noted, however, that these elements were mostly just opposite the protoxylem-groups, usually in contact with them (i. e. without the intervention of a layer of parenchyma), and that none of them were found in an immature condition. It is also important that, internal to the peripheral scalariform element of one of these apparently mesarch groups, there may be one or more tracheides with rather dense spiral thickening before one reaches the smallest tracheide characterized by a loose spiral, and even a form of thickening transitional between scalariform and spiral may be met with between the tracheides with these two types of thickening. Thus if one disregards the scalariform tracheides (as being possibly secondary) the evidently primary elements outside the protoxylem indicate mesarch differentiation.

1 Bertrand ('81), Fig. 208 on p. 482, Dangeard ('91), Pl. IX, Fig. 4 and Pl. XII, Fig. 7, for diarch structure. Dangeard ('91, p. 206) states that in the ramifications of the rhirome 'la stele binaire peut perdre son caractère de détermination.'

' In the region where fivo or more xylem-rays are present. 
Hence, though examination of young shoots showing a suitable stage of differentiation at this level is required, one may provisionally regard local mesarch structure as established for Psilotum, and the most natural conclusion is that the structure of its aerial stem has been reduced from the mesarch to the exarch type in connexion with the disappearance of the leaf-traces. Psilotum and Tmesipteris might then be referred to a common parent-form, in which the aerial stem had a rayed mesarch xylem-mass, the suppression of leaf-traces having caused the loss of centrifugal wood in the one genus, and the influence of the leaf-traces in the other genus having broken up the xylem into distinct bundles. If we make a comparison once more with Cheirostrobus, it is interesting that in that plant there are indications of .mésarch structure ${ }^{1}$ (see Scott, '97, p. 9, footnote, and Pl. IV, Fig. I), and that towards the centre of the stele a considerable amount of parenchyma is found separating the tracheides (Scott, '97, PI. I, Phot. 3). This parenchyma might easily become converted into sclerotic tissue in response to mechanical requirements, the intervening tracheides becoming replaced by similar elements ${ }^{2}$.

The material of Psilotum triquetrum, which was chiefly used for this investigation, was a plant which had lain in spirit for several years, and was probably grown at Kew, though its origin had not been recorded: For comparison fresh specimens of one or two old aerial shoots with adjacent subterranean parts were obtained from a plant grown at Kew, and these showed the same structural characters.

\section{SUMMARY.}

The solid mass of tracheides described and figured by Bertrand in the subterranean parts of Psilotum triquetrum does not represent the whole of the xylem present in parts of the specimens examined, but additional tracheides are found outside it but internal to the ring of sieve-tubes.

These tracheides are formed considerably later than those of the central mass, and show successive and somewhat irregular development. Certain of them are to be found still incompletely differentiated in quite old parts

1 And that secondary xylem is present in the pedancle of the cone (Scott, '97, p. 15, and Pl. VI, Fig. 21).

2 It may be mentioned here that in a large aerial branch of Psilotum, preparation for the first dichotomy by the appearance of one tracheide in the middle of the central sclerotic tissue of the stele occurred at four inches below the fork. At two and a half inches below the latter there were eight tracheides in this position, and the group then increased in size to form a bridge across the sclerenchyma, afterwards splitting for the dichotomy of the stele. This differs from Bertrand's description ('81, p. 405 et seq. and Fig. 179) and may be exceptional. In Tmesipteris Bertrand (81, p. 494 and Fig. 215) mentions that occasionally certain of the xylem-strands are interior with regard to the rest, and figures a small strand of five tracheides placed roughly at the centre of the pith, which is surrounded by a ring of six xylem-groups. It is possible that this central group may hare some sach connexion with the branching of the stem, as in the case just referred to io Prilotum. 
of the stem. They are to be regarded as reduced secondary xylem, and they are present in the aerial as well as subterranean stem.

There is no definite cambial layer, but radial arrangement among the parenchyma and tracheides is often found, and parenchymatous rays opposite the protoxylems are sometimes present.

- The secondary tracheides are scalariform or irregularly pitted, and often have a sinuous course.

The presence of secondary tracheides around a triarch primary xylem, such as occurs in some parts of the stem, gives a close approximation to the structure of the stem of Sphenophyllum.

: In the lower region of the aerial stem a few cases of apparent mesarch structure were observed: If this should be verified, an important distinction between Psilotum and Tmesipteris would break down, and a further agreement between the aerial stem of Psilotum and the axis of Cheirostrobus (already rather. striking) would be established.

Thus the new facts derived from a study of the vegetative anatomy strengthen the hypothesis of the affinity of the Psilotaceae with the Sphenophyllales. This view; put forward by Scott and adopted by Thomas and Bower, was founded partly on the vegetative anatomy, but more especially on the characters of the sporophylls.

The production of secondary tracheides in subterranean parts is probably.dependent on the development of aerial shoots, and appears to be due to a basipetal stimulus from the latter.

In conclusion I wish to express my thanks to Dr. D. H. Scott, F.R.S., for valuable suggestions and criticism and for information regarding Sphenophylleae.

$1, \cdot \cdots$

\section{LIST OF WORKS REFERRED TO.}

Bratrand ('81): Recherches sur les Tmesipterldtes, Archives botaniques du Nord de la France, tome i, p. 252.

Boodle ('99) : On rome points in the anatomy of the Ophioglosseac, Annals of Botany, rol. xiii, p. 377 .

Bown ('03): Studies in the morphology of spore-producing members. No. V. General Comparisons and Conclusion, Phil. Trans. Roy. Soc., Series B, vol. 196, p. 19 r.

Brongniart ('B7) : Histoire des régétaux fossiles, ii.

Dangrard ('91): Mém. sor la morphologie et l'anatomie des Tmesipteris, Le Botaniste, 2' setr., $1890-189 \mathrm{I}$, p. I63.

De Bary (77): Comparative Anatomy of the Phanerogams and Ferns (Engl. Ed, '84).

Lrgmigr ('03): Equirétales et Sphénophyllaler. Leur origine filicintenne commane, Bull. Soc, Linndenne de Normandie, $5^{\bullet}$ série, $7^{\circ}$ vol., p. 93.

LINK (42): Icones selectae anatomico-botanicae, fasc. ir. 
NüGïL (68) : Das Wachsthum des Stammes, Beitr. zur wissensch. Bot., Heft I.

NÄGELI and LeITGeB ('68): Entstehang a. Wachstham der Warzeln, Beitr. xur wissensch. Bot., Heft IV, p. 73.

Pritzer ('00) : Psilotaceae in Engler and Prantl, Die natürl. Pflanzenfam., I. Teil, Abt. 4, p. 606.

Russow ('72): Vergleichende Untersuchungen, Mém. de l'Acad. de St.-Pétersbourg, $7^{\bullet}$ sér., t. xix, no. I.

(76): Betrachtungen über das Leitbündel- und Grondgewebe.

SCOTT ('00): Studies in Fossil Botany.

('97): On Cheirostrobus, Phil. Trans, series B, vol. I89, p. I.

Solms-Laubach ('81): Der Aufban des Stockes von Psilotum triquetrum, Ann. Jard. Bot. de Buitenzorg, iv.

Thomas (02): The affinity of Tmesipheris with the Sphenophyllales, Proc. Roy. Soc, vol. lxix, p. 343 .

Wilisamson ('74): On the organization of the Fossil Plants of the Coal-Measures, Part V, Phil. Trans., 1874, P. 41 .

\section{EXPLANATION OF FIGURES IN PLATE XXXIII.}

Ullostrating Mr. Boodle's paper on Psilotwm.

Figs. I 6 are photographs from sections of Psilotum triquetrum stained with methyl-green and eosine; they are all $\times 90$.

Fig. 1. Transverse rection of rhizome, showing primary structure only. The xylem consists of a solid group of nine tracheides (seven quite distinct and two small paler one on the left). e, endodermis; s. t., sieve-tubes.

In Figs. 2-6 numerous secondary tracheides are present, many of them being incompletely lignified and therefore stained dark.

Fig. 2. Transverse section of the stem, cut at $d$ in Text-Fig. 44. The large pale-walled primary tracheides $(p)$ are surrounded by a large number of secondary tracheides.

Fig. 3. Traneverse section of the stem, cut at $c$ in Text-Fig. 44. s, a group of secondary tracheides. Primary xylem band-shaped and probably diarch.

Fig. 4. Transverse section of the stem, cut at $a$ in Text-Fig. 44. Primary xylem band-shaped.

Fig. 5. Transverse section of the stem cot half-way between $a$ and $b$ in Text-Fig. 44. Primary xylem triarch. $r$, parenchymatous ray opposite one of the protoxylem-group.

Fig. 6. Transverse section of the stem, cut at $b$ in Text-Fig. 44. Xylem triarch. Radial arrangement of elements shown at $r$. 

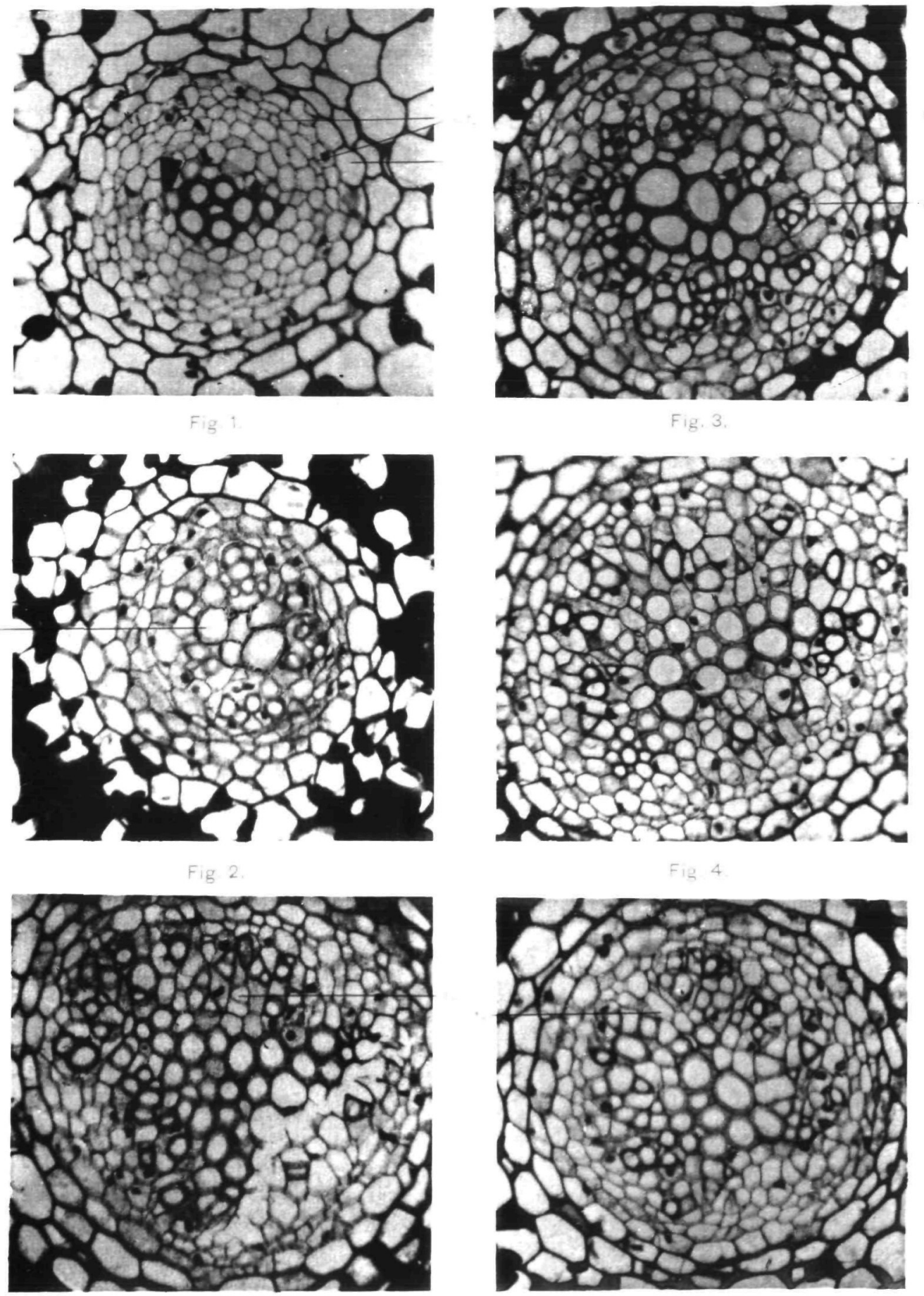

Fig. 6.

Fig. 5. 
Downloaded from https://academic.oup.com/aob/article-abstract/os-18/3/459/170393 by University of California, Santa Barbara user

on 09 March 2018 